Y/TS-1264

\section{$Y-12$}

OAK RIDGE

$Y-12$

PLANT

MARETM MARUETTA
MANAGED BY

MARTIN MARIETTA ENERGY SYSTEMS, INC.

FOR THE UNITED STATES

DEPAATMENT OF ENERGY
INSIGHTS INTO QUICK FLOW IN A KARST AQUIFER:

USEFULNESS OF INFREQUENTLY COLLECTED GEOCHEMICAL DATA FROM WELLS

\author{
L. A. Shevenell \\ Nevada Bureau of Mines and Geology
}

November 1994

Submitted to:

Applied Geochemistry

Prepared for the

Environmental Management Department

Health, Safety, Environment, and Accountability Organization

Oak Ridge Y-12 Plant

Oak Ridge, Tennessee 38731

managed by

MARTIN MARIETTA ENERGY SYSTEMS, INC. for the

U.S. DEPARTMENT OF ENERGY under contract

DE-A C05-840R21400

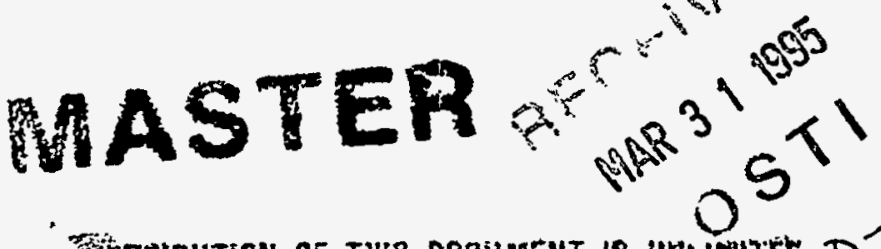




\section{DISCLAIMER}

This report was prepared as an account of work sponsored by an agency of the United States Government. Neither the United States Government nor any agency thereof, nor any of their employees, makes any warranty, express or implied, or assumes any legal liability or responsibility for the accuracy, completeness, or usefulness of any information, apparatus, product, or process disclosed, or represents that its use would not infringe privately owned rights. Reference herein to any specific commercial product, process, or service by trade name, trademark, manufacturer, or otherwise, does not necessarily constitute or imply its endorsement, recommendation, or favoring by the United States Government or any agency thereof. The views and opinions of authors expressed herein do not necessarily state or reflect those of the United States Government or any agency thereof.

\section{COPYRIGHT NOTICE}

The submitted manuscript has been authored by a contractor of the U.S. Government under contract DE-AC05-840R21400. Accordingly, the U.S. Government retains a paid-up, nonexclusive, irrevocable. worldwide license to publish or reproduce the published form of this contribution. prepare derivative works, distribute copies to the public. and perform publiciy and display publicly, or allow others to do so, for U.S. Government purposes. 


\section{DISCLAIMER}

Portions of this document may be illegible in electronic image products. Images are produced from the best available original document. 


\title{
INSIGHTS INTO QUICK FLOW IN A KARST AQUIFER: \\ USEFULNESS OF INFREQUENTLY COLLECTED GEOCHEMICAL DATA FROM WELLS
}

Prepared by:

\author{
L. A. Shevenell \\ Nevada Bureau of Mines and Geology \\ University of Nevada, Reno
}

Submitted to:

Applied Geochemistry
Prepared for the
Environmental Management Department
Health, Safety, Environment, and Accountability Organization Oak Ridge Y-12 Plant
Oak Ridge, Tennessee 37831

\author{
managed by \\ MARTIN MARIETTA ENERGY SYSTEMS, INC. \\ for the \\ U.S. DEPARTMENT OF ENERGY \\ under contract DE-AC05-84OR21400
}

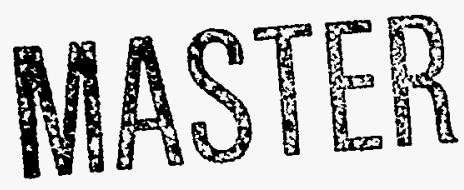


Insights into quickflow in a karst aquifer: Usefulness of infrequently collected geochemical data from wells

\author{
Lisa Shevenell \\ Nevada Bureau of Mines and Geology, University of Nevada, Reno \\ MS 178, Reno, NV 89557-0088, U.S.A.
}

\begin{abstract}
Highly variable chemical characteristics (e.g., hardness) can indicate that a portion of a karst aquifer sampled by a well is subject to a quickflow component where water flow is rapid and water quality changes rapidly in response to precipitation events. Typically, karst aquifer monitoring for both water level and geochemistry is conducted at frequent intervals (hourly, daily) due to the nature of rapid geochemical and hydrologic changes in association with storm events. However, when other types of data are available from less frequent monitoring, these data should not be discounted because useful information on the nature of flow through the karst system can be obtained.
\end{abstract}

Quarterly monitoring data are available at the U.S. Department of Energy Oak Ridge Y-12 Plant* in Oak Ridge, TN, and these data are evaluated to identify quickflow portions of the aquifer. Values of $\mathrm{PCO}_{2}$ near atmospheric suggest rapid recharge of fluids, and 12 of 99 well waters exhibited $\mathrm{PCO}_{2}$ near atmospheric. Waters saturated with respect to dolomite must have relatively long residence times because attainment of saturation requires tens to hundreds of years. Repeat sampling of waters shows that both supersaturation and undersaturation with respect to dolomite occurs in 46 wells, indicating that relatively old waters diffusing from the rock matrix into conduits during baseflow experience periodic flushing by more rapidly recharged waters. Undersaturation with respect to calcite indicates active dissolution and may suggest short residence times because calcite saturation can be expected to occur on the order of days. Ten of the well waters were consistently undersaturated with respect to calcite, with numerous others being undersaturated for at least one sampling event. Evaluation of $\mathrm{a} \mathrm{Mg} / \mathrm{aCa}$ ratios in the waters allows identification of portions of the aquifer where flow occurs from a dolomite to a limestone, and vice versa. In addition, 30 well waters exhibited coefficients of variation of hardness $>10 \%$. Hence, quickflow was identified in association with numerous well waters even though only quarterly monitoring data were available.

\title{
INTRODUCTION
}

The chemical characteristics of waters sampled be wells in karst aquifers can provide insight into the behavior of the aquifer system. Highly variable chemical characteristics (e.g., hardness) can indicate that the portion of the aquifer sampled by a particular well is subject to a quickflow component where recharge to the system may be quite rapid, water flow through conduits is quick, and water quality changes rapidly in response to precipitation events.

Typically, karst aquifer monitoring for both water level and geochemical characteristics is considered at frequent intervals (hourly, daily) due to the nature of rapid geochemical and hydrologic changes in association with storm events (e.g., Mahler and Bennett, 1992; Worthington, 1992; Back and Zoetl, 1975). Rapid changes in water level and geochemistry in karst aquifers can occur on the order of hours following initiation of a precipitation even. Hence, samples collected weekly, monthly, or quarterly are quite likely to miss important data, which illustrates quickflow behavior through the karst aquifer. It is widely accepted that monitoring of karst aquifers need be conducted on much more frequent basis than quarterly in order to acquire data relevant to quickflow rather than averaged hydrologic conditions.

* Managed by Martin Marietta Energy Systems, Inc. for the U.S. Department of Energy under contract DE-AC05-840R21400. 
However, several years of quarterly monitoring data are available from a karst aquifer at the Department of Energy, Y-12 Plant in Oak Ridge, Tennessee, U.S.A (Y-12 Plant). Geochemical data collected during quarterly monitoring may not identify quickflow behavior through the variability of chemical constituents between storm events because the sampling interval is too long. The geochemical data may suggest diffuse recharge and slow subsurface flow when the study site would actually exhibit significant chemical variability suggestive of quickflow if shorter sampling intervals were employed. Frequently obtained geochemical data are not available for the karst aquifer at the Y-12 Plant, hence, it is prudent to evaluate existing, quarterly data, recognizing the limitations of such data. Large amounts of chemical variability illustrated with this type of data will lead to the conclusion that quickfiow is important in the portion of the aquifer being studied. However, lack of such data is inconclusive due to poor timing of sample collection. It is hypothesized that use of quarterly monitoring data in a karst aquifer will provide useful information related to the characteristics of the flow system even though this type of data is not optimum for use in karst aquifer systems.

Several ideas and concepts pertaining to the nature, extent, and the behavior the karst aquifers at the Y-12 Plant require refinement. Interpretation of the geochemical characteristics of the groundwaters is one component in an overall effort of aquifer characterization. The purpose of this work is to (1) better define groundwater interaction between the adjacent karst formations of the Maynardville Limestone (Cmn) and the Copper Ridge Dolomite (Ccr), (2) identify portions of the aquifer in which fractures and conduits may currently be subject to enlargement through dissolution, and (3) identify portions of the aquifer which are likely to be subject to a rapid component of flow (quickflow).

\section{BACKGROUND}

Profound effects on contaminant transport rates may result when waste disposal facilities are located on or adjacent to a karst aquifer. Several waste disposal sites are located adjacent to a karst aquifer composed of the Cambrian Maynardville Limestone ( $\mathrm{Cmn}$ ) and the Cambrian Copper Ridge Dolomite (Ccr), at the Oak Ridge Y-12 Plant. The Cmn, which underlies the southern portion of Bear Creek Valley (BCV; Fig. 1), is considered to be the primary pathway for groundwater leaving the Y-12 Plant (King and Haase, 1988). Because water in the Cmn is believed to interact with that in the Ccr, dominantly through recharge occurring in the $\mathrm{Ccr}$, the chemical characteristics of both formations are investigated. Description of geologic features of the Cmn can be found in Goldstrand, (in press), Goldstrand et al. (in prep.), and Shevenell et al. (1992).

Numerous cavities have been identified in both the $\mathrm{Ccr}$ and $\mathrm{Cmn}$ during drilling of monitoring wells. Sixty-seven percent of all wells drilled into the $\mathrm{Cmn}$ have intersected at least one cavity, whereas $64 \%$ of the wells drilled into the Ccr have encountered at least one cavity. Cavities in the Cmn are submerged and mud filled, and tend to be smaller ( $52 \%$ of known cavities are 0.3 to $1.5 \mathrm{~m}$ in vertical dimension) than those in the Ccr in which $12 \%$ of all cavities encountered have been $>3 \mathrm{~m}$ in vertical 
dimension. Also, the Ccr cavities are often located at or above the water table. In the $\mathrm{Cmn}$, most cavities are relatively shallow $(<45 \mathrm{~m}$ ), with the frequency of cavities decreasing with increasing depths, and the frequency of fractures decreasing with increasing elevation as they become subject to dissolution, thus forming cavities at the higher elevations (Shevenell and Beauchamp, 1994; Shevenell, et al., 1992).

\section{PROCEDURE}

Historical data from wells at the Y-12 Plant, were compiled and evaluated for general chemical characteristics and temporal variability. The data were obtained from several sources: Groundwater Quality Assessment Reports (GWQAR; HSW, 1991a, 1991b, 1991c, 1992a, 1992b, 1992c), a SAS data base maintained in the Environmental Sciences Division, Oak Ridge National Laboratory (Thompson, 1993), and data from multilevel (Westbay) monitoring wells (Dreier et al., 1993; Shevenell and Dreier, unpub. Westbay monitoring data). The wells selected are completed in either the Ccr or the Cmn. Most of the available data are in the form of chemical analyses obtained from quarterly sampling of individual wells.

All available data were compiled and charge balances calculated for each sample. All samples which had a charge balance in excess of $\pm 10 \%$ were eliminated from the data set resulting in a data set containing 99 wells or multiport zones which have been sampled between 1 and 20 times between 1986 and the first two quarters of 1992.

Saturation indices were calculated to determine which portions of the system may currently be subject to enlargement of fractures and conduits by dissolution. Saturation indices (SI) and carbon dioxide partial pressures $\left(\mathrm{P}_{\mathrm{CO}_{2}}\right)$ were calculated using the equilibrium aqueous speciation model SOLMINEQ.88 (Kharaka et al., 1988). Data for calculation of dolomite SI in SOLMINEQ.88 were substituted with equilibrium constant data for dolomite from Langmuir (1971) where

$$
\mathrm{pK}_{\mathrm{d}}=0.0207 \mathrm{~T}\left({ }^{\circ} \mathrm{C}\right)+16.513 \quad\left(\mathrm{R}^{2}=0.987\right) \text {. }
$$

In order to evaluate the variability of hardness between sampling events, the equivalent $\mathrm{CaCO}_{3}$ hardness (in $\mathrm{mg} / \mathrm{L}$ ) was calculated after Drever (1982):

$$
\text { equivalent } \mathrm{CaCO}_{3}=2.5(\mathrm{mg} / \mathrm{L} \mathrm{Ca})+4.1(\mathrm{mg} / \mathrm{L} \mathrm{Mg})
$$

Using these calculated values, the coefficient of variation of hardness (CV; standard deviation divided by the mean) was calculated for each well. The flow through time (recharge to point of measurement) was then estimated using Ternan's (1972) power law which is based on the carbonate content of springs and flow through time determined by Pitty (1968; 1971). The Ternan relationship is

$$
\mathrm{CV}=35 \mathrm{t}^{-0.524}
$$

where $t$ is the flow through time in days. Equation 4 is expected to yield reasonable results for small drainage basins $\left(<100 \mathrm{~km}^{2}\right)$ in temperate climates (White, 1988) such as that at the Y-12 Plant. 
The discharge ( $Q$ in $\mathrm{m}^{3} / \mathrm{s}$ ) associated with a water's hardness can be estimated from which flow volume near different well locations can be compared. Bassett and Ruhe (1973) studied the Lost River watershed in southern Indiana and found that hardness $\left(\mathrm{H}_{d}\right)$ is related to discharge at springs via equation 5:

$$
H_{d}=402.7-113.2 \log (Q), \quad R^{2}=0.81 \text {. }
$$

Although the empirical expressions in equations (4) and (5) were not developed using well data, the results should provide order-of-magnitude estimates and values to be used for comparative purposes for the flow through times and volumes of water flow expected in different portions of a system.

\section{RESULTS}

\section{Hardness}

Equivalent $\mathrm{CaCO}_{3}$ hardnesses of sampled waters were calculated using equation (2) and a summary of results appears in Appendix A. Most hardness values fall in the range of 100 to $500 \mathrm{mg} / \mathrm{L}$ in both the $\mathrm{Ccr}$ and $\mathrm{Cmn}$. The highest values (>1000 mg/L) are associated with eight of the deeper (>135 m) wells which contain high concentrations of $\mathrm{SO}_{4}$ and $\mathrm{Cl}$ which suggests that these wells tap waters which are interacting to varying degrees with an underlying brine (Haase, 1991).

The calculated CV range from 0 to 0.47 indicating that several of the wells intersect zones which are subject to a significant quickflow component. The highest CV values $(\geq 0.20)$ are generally found in wells which are known to intersect cavities or fractures. For instance, the highest CV (0.47) is found in GW-734 which intersects a large, mud-filled cavity which exhibits flashy water level changes in response to precipitation (Shevenell et al, 1992). Water levels have been observed to rise in this well only 1 to 6 hours following initiation of precipitation. However, another well intersects a slower flowing water zone (GW-223) and has a very high CV (CV= 0.26, for filtered samples). The high value in $G W-223$ probably reflects some influence from quickflow near the location of the well bore.

The estimated flow through times (Appendix A) from equation 4 are based on the CV and subject to the same limitations resulting from timing of sample collection (ie. quarterly rather than daily or

hourly). The values of flow through can be used in a relative sense. For instance, flow from recharge to the location of well GW-061 (depth $=7.6 \mathrm{~m}$ ) could be as rapid as 1.5 days, suggesting relatively rapid flow. Long transit times of 11 to 25 days are suggested for $G W-056$ (depth $=16.8 \mathrm{~m}$ ). Note that several wells (1090, GW-154, GW-155, GW-174, GW-298) have much higher CV for the unfiltered samples when compared to the filtered samples indicating either transport of colloids or larger particulates within the aquifer water, or possibly disturbance of colloids and particulates in the aquifer near the well bore during some sampling events.

Estimations of discharge (Q) are listed in Appendix A. The calculated discharge associated with GW-174 is an order of magnitude larger than that estimated at GW-179, which may be reasonable given 
that water level fluctuations over the course of one year are $9.1 \mathrm{~m}$ in GW-174 and $\leq 3 \mathrm{~m}$ in GW-179 (depths of $44 \mathrm{~m}$ and $35.7 \mathrm{~m}$, respectively). It should be noted that large water level fuctuations over the course of one year are not necessarily associated with the presence of cavities because water level fluctuations are a function of transmissivity and storage. A relatively impermeable unit with low storage (or dead-end fractures) could also respond with large water level changes. The similar responses in these two different situations can be distinguished by measurement of water level, temperature and specific conductance (SC) during a storm event and identifying the lag time between precipitation and water level rise, and between water level rise and changes in SC and temperature. In a low permeability formation, rapid water level changes will not be associated with changes in SC and temperature, and hence, groundwater flow, but may simply reflect a pressure change within the aquifer. This type of monitoring data is not currently available.

Nevertheless, GW-179 apparently experiences less influence from quickflow, which is also suggested by the partial pressure of $\mathrm{CO}_{2}\left(\mathrm{P}_{\mathrm{CO} 2}\right)$ data discussed in a later section. $\mathrm{GW}-174$ has $\mathrm{P}_{\mathrm{CO} 2}$ values near atmospheric, whereas GW-179 does not suggesting longer average residence time in the unsaturated zone and slow percolation to the water in by GW-179. Without independent estimates for the volume flow through a particular cross-sectional area, it is not possible to determine the extent to which the numbers reflect reality. It may be possible to calibrate Equation 5 to conditions encountered on the ORR. Point dilution tests could be used to estimate specific discharge $(\mathrm{q})$ or volumetric discharge $(\mathrm{Q}=\mathrm{qA})$ in a bore hole interval (Hicks et al., 1992). The values of $Q$ could be compared between the two methods to determine the extent to which Equation 5 may be valid on the ORR.

\section{Saturation indices}

The minimum and maximum values for dolomite and calcite SI's for water samples from the wells in the study area appear in Table 1. The SI's are calculated to determine which well waters are undersaturated with respect to calcite, and this provides an indication of whether the particular zone monitored is currently subject to calcite dissolution. Equilibrium and supersanuration with respect to dolomite provide a rough indication of fluid residence times. It is expected that waters require 10's to 100's of years to attain saturation with respect to dolomite because the kinetics of dissolution are very slow at SI greater than $\approx-2$ (Busenberg and Plummer, 1982). Waters saturated with respect to dolomite are likely to be of the slow-flow type, perhaps recharged by slow percolation through the vadose zone, and subsequently flowing through less permeable regions of the aquifer, thus allowing sufficient interaction time with aquifer rocks during which equilibrium can be attained. Waters which exhibit fluctuations in their dolomite saturation indices between supersaturation and undersaturation are suggestive of changing flow conditions between the sampling events. At times of supersaturation, waters sampled are likely to reflect baseflow conditions when sufficient time for equilibration is available. During these times, samples are dominantly matrix water which has not been significantly diluted with recently recharged waters. When these same well waters exhibit undersaturation during subsequent sampling, this suggests that the zone 
tapped is subject to a relatively quickflow component which dominates during precipitation events when much less time is available for recharging waters to interact with the aquifer rocks, and aquifer waters in the conduits and fractures become diluted.

Consistent undersaturation with respect to calcite is suggestive of relatively young, quick flowing water because only a few days are typically required to reach saturation. Ten wells have been consistently undersaturated with respect to calcite over the sampling events, and the zones tapped are currently subject to dissolution. Table 1 highlights these wells in italics for the calcite saturation indices, as well as highlighting other wells for which only one analysis is available to suggest undersaturation with respect to calcite.

Many cavities in the Cmn are mud filled (ie. GW-734) suggesting that at some time in the past, flow velocities either decreased as the conduit size increased through dissolution, or as a result of decreases in hydraulic gradients. Note that decreases in the hydraulic gradient in the system occurred within the past 50 to 60 years as the base level (Clinch River) rose following construction of Watts Bar and Melton Hill Dams (see Fig. 1). As fluid velocities decreased, it is likely that sediment accumulated on the floors of the conduits, and solutional attack continued on the ceiling as the sediment accumulated (paragenesis; Ford and Ewers, 1978). Upward dissolution of carbonates in the Cmn conduits may continue until the tops of the passages intersect the piezometric surface.

The minimum (Min) and maximum (Max) measured SI for calcite and dolomite, the number of analyses available (\# of Values), and the maximum variability in the saturation calculated by subtracting the minimum SI from the maximum SI (Min-Max) appear in Table 1. Of the well waters for which repeat analyses are available, the following are consistently supersaturated with respect to dolomite and, therefore, are likely have relatively long mean residence times: GW-511, GW-695, GW-704, GW-712 (only 2 samples). However, a small component of quickflow may occur in three of the wells (GW-511, GW-695, and GW-704) as suggested by $C V \geq 0.10$ in each of these wells, but insufficient numbers of samples may have been collected thus far from which to detect the quickflow effects. Twenty-two other wells (see Table 1) only have one reliable analysis, yet also indicate supersaturation with respect to dolomite. The SI in 46 wells fluctuates from supersaturated to undersaturated with respect to dolomite (bold entries in the SI(dol) Min and Max columns of Table 1).

\section{Partial pressure of carbon dioxide}

It is reasonably assumed that $\mathrm{P}_{\mathrm{CO} 2}$ values near atmospheric (ie. $-\log \left(\mathrm{P}_{\mathrm{CO} 2}\right) \approx 3.5 \mathrm{~atm}$ ) are indicative of waters in quickflow regimes where insufficient time has elapsed for waters to deviate from equilibrium with amospheric $\mathrm{CO}_{2}$ since recharge. For instance, $\mathrm{CO}_{2}$ concentrations in soil gases can be 6 to 10 times greater than that in the atmosphere (Russell and Appleyard, 1915; Boynton and Reuther, 1938). Hence, waters recharging an aquifer through the soil zone can acquire significant $\mathrm{CO}_{2}$ concentrations as waters interact with soil gases. Near atmospheric $\mathrm{CO}_{2}$ suggests limited residence times in the soil zone, and 
hence, rapid recharge to the aquifer. Twelve well waters had close to atmospheric $\mathrm{P}_{\mathrm{CO} 2}$ values $\left(-\log \left(\mathrm{P}_{\mathrm{CO}_{2}}\right)\right.$ $=3.5 \pm 0.3 \mathrm{~atm}$ ) during at least one sampling event (wells followed by an $*$ in Table 1). A relatively short fluid residence time between recharge and the well location is suggested in these cases.

Some of the waters have $\mathrm{P}_{\mathrm{CO} 2}$ much less than atmospheric for one or more sampling events (GW-099, $\mathrm{P}_{\mathrm{CO} 2}=4.22 ; \mathrm{GW}-158, \mathrm{P}_{\mathrm{CO} 2}=4.28 ; \mathrm{GW}-174, \mathrm{P}_{\mathrm{CO} 2}=4.00 ; \mathrm{GW}-511, \mathrm{P}_{\mathrm{CO} 2}=4.21$ to 5.56; and

GW-723, $\mathrm{P}_{\mathrm{CO} 2}=4.08$; see Shevenell, 1994 for complete data). Closed system dissolution of calcite could result in low $\mathrm{P}_{\mathrm{CO} 2}$ values such as these (Drever, 1988, pg 68-69).

\section{Magnesium to calcium ratios}

The ratios of $\mathrm{Mg}$ to $\mathrm{Ca}$ activities for some of the wells appears in Table 2 (complete data appear in Shevenell, 1994). The $\mathrm{a}_{\mathrm{Mg}} / \mathrm{a}_{\mathrm{Ca}}$ ratio in individual wells ranges from 0.08 to 1.62 in Cmn wells, and between 0.26 and 4.11 in $C c r$ wells. Generally higher $\mathrm{a}_{\mathrm{Mg}_{\mathrm{g}}} / \mathrm{a}_{\mathrm{Ca}}$ ratios in the $\mathrm{Ccr}$ are to be expected because the formation is a dolomite. A ratio $\geq 0.6$ in waters is expected when dolomite is more stable than calcite (Drever, 1988), and these higher ratios are assumed to be representative of waters in the $\mathrm{Ccr}$ in this study.

Low $\mathrm{a}_{\mathrm{Mg}} / \mathrm{a}_{\mathrm{Ca}}$ ratios obtained from the $\mathrm{C} c \mathrm{r}$ well $\mathrm{GW}-683$ ( 0.41 to 0.59 ) appears anomalous. The lower $\mathrm{Mg}$ to $\mathrm{Ca}$ ratios in $\mathrm{GW}-683$ (Picket $\mathrm{A}$ ) may be suggestive of relatively short residence times in the Ccr. During drilling of this well, there was significant water production from the completion zone, and an increase in turbidity occurred in a spring $\approx 130 \mathrm{~m}$ north of the well (Shevenell et al., 1992) suggesting an interconnected, quickflow system was tapped by GW-683. Also, the $\mathrm{a}_{\mathrm{Mg}} / \mathrm{a}_{\mathrm{Ca}}$ ratio in GW-683 of $0.47 \pm$ 0.06 suggests flow from the $\mathrm{Cmn}$ to the $\mathrm{Ccr}$ under Chestmut Ridge in the vicinity of Picket $\mathrm{A}$ (Fig. 1; where pickets identify five areas in which wells were drilled specifically to investigate the karst $\mathrm{Cmn}$ ). The interaction between the $\mathrm{Cmn}$ and $\mathrm{Ccr}$ is corroborated by $\mathrm{NO}_{3}$ analyses which show $\mathrm{GW}-683$ contains 3 to $22 \mathrm{mg} / \mathrm{L} \mathrm{NO}_{3}$. The only source for the $\mathrm{NO}_{3}$ is the up-gradient S-3 Ponds plume which is migrating westward, along strike in the Cmn (Shevenell et al., 1994), and apparently entering the Cer at or to the east of Picket A (Fig. 1).

Thirty-three of the 73 (45\%) $\mathrm{Cmn}$ sampling zones have $\mathrm{a}_{\mathrm{Mg}} / \mathrm{a}_{\mathrm{C}_{3}}$ ratios of $>0.6$ (Table 2). Wells containing an " $\mathrm{F}$ " in the column "Consistent or Fluctuating" did not consistently have $\mathrm{a}_{\mathrm{Mg}} / \mathrm{a}_{\mathrm{Ca}}>0.6$; all of these wells also showed fluctuations in the dolomite SI's. The Cmn wells followed by "Y" in the "Drilled Through the Ccr" column were drilled on Chestmut Ridge through the Ccr, and recharge to these zones in the $\mathrm{Cmn}$ is likely to have passed through the $\mathrm{Ccr}$, acquiring chemical characteristics of this formation. The other wells are drilled entirely within the $\mathrm{Cmn}$. The higher $\mathrm{a}_{\mathrm{Mg}} / \mathrm{a}_{\mathrm{Ca}}$ ratio in the wells listed suggests that a portion of the recharge water in these zones is through the Ccr. Flow toward these wells from the Ccr is apparently sufficient to dominate the water chemistry in the Cmn wells in that the Ccr fluid is not significantly diluted relative to $\mathrm{Mg}$ once entering the $\mathrm{Cmn}$. Some $\mathrm{Cmn}$ wells throughout the length of $\mathrm{BCV}$ show interaction with the $\mathrm{Ccr}$. 
Two Cmn zones (GW-135-06 and GW-135-11) have $\mathrm{a}_{\mathrm{Mg}} / \mathrm{a}_{\mathrm{Ca}}<0.6$ (Shevenell, 1994), yet these zones are also located beneath the Ccr. GW-135-06 is a water which has apparently undergone a small amount of mixing with the underiying brine ( $\mathrm{GW}-135-06 \mathrm{Cl}=580 \mathrm{mg} / \mathrm{L}, \mathrm{Na}=510 \mathrm{mg} / \mathrm{L}$ ) as well as having encountered gypsum along a flow path $\left(\mathrm{SO}_{4}=1623 \mathrm{mg} / \mathrm{L}\right)$. Relatively high $\mathrm{SO}_{4}(700 \mathrm{mg} / \mathrm{L})$ in GW-135-11 indicates this water also dissolved gypsum along its flow path. Hence, each of these waters likely has excess $\mathrm{Ca}$ as a result of dissolution of $\mathrm{CaSO}_{4}$, thus altering the $\mathrm{a}_{\mathrm{Mg}} / \mathrm{a}_{\mathrm{Ca}}$ ratio expected from a purely dolomitic host rock.

Several Cmn water zones in GW-722 $(-2,-10,-17,-22$, and -30$)$ have $a_{\mathrm{Mg}} / \mathrm{a}_{\mathrm{Ca}}>0.6$ and are undersaturated with respect to calcite for the one sampling event available for each. This undersaturation is suggestive of dissolution, yet is not indicative of quickfiow given that flow to these zones is predominantly through dolomitic rocks, as the $\mathrm{a}_{\mathrm{Mg}} / \mathrm{a}_{\mathrm{Ca}}$ data show.

Use of simple mixing models (measured value $=x(\mathrm{Cmn})+(1-\mathrm{x})(\mathrm{Ccr})$ ) to predict the percentage of $\mathrm{Ccr}$ water mixed with the $\mathrm{Cmn}$ water was unsuccessful. The average of all $\mathrm{Cmn}$ waters with $\mathrm{a}_{\mathrm{Mg}} / \mathrm{a}_{\mathrm{Ca}}<$ 0.6 is $0.35 \pm 0.14$, whereas the average of all Ccr with $\mathrm{a}_{\mathrm{Mg}} / \mathrm{a}_{\mathrm{Ca}}>0.6$ is $1.03 \pm 0.09$. If only equilibrated waters are used to calculate the $\mathrm{a}_{\mathrm{Mg}} / \mathrm{a}_{\mathrm{Ca}}$ ratio, the average in the $\mathrm{Cmn}$ for water at equilibrium or supersaturated with respect to calcite is $0.57 \pm 0.28$, and that for the $C c r$ for water at equilibrium or supersaturated with respect to dolomite is $1.0 \pm 0.12$. The measured ratios in several $\mathrm{Cmn}$ wells with $\mathrm{a}_{\mathrm{Mg}} / \mathrm{a}_{\mathrm{Cg}}>0.6$ are greater than the average in the Ccr. Hence a negative amount of $\mathrm{Cmn}$ water is indicated suggesting a simplistic mixing model is not appropriate to describe the interaction between the Car and Cmn in these wells, which is understandable considering the dynamic chemical behavior in each formation. Other endmember $a_{M g} / a_{C a}$ values such as the average $C m n$ water without wells which may have an influence from the $\operatorname{Ccr}\left(a_{\mathrm{Mg}} / \mathrm{a}_{\mathrm{Ca}}=0.34 \pm 0.14\right)$ show the same discrepancies.

$\delta D$ and $\delta^{18} \mathrm{O}$ data

Stable isotope ratios have only been measured in a small percentage of waters (Table 3). The data show little variation in $\delta^{18} \mathrm{O}(-7.72$ to -6.54 per mil), likely because recharge elevations are approximately the same for all sampled waters due to the small amount of local relief (90 to $150 \mathrm{~m}$ difference between ridges and valleys). Fig. 2 is a plot of $\delta \mathrm{D}$ versus $\delta^{18} \mathrm{O}$ where the "X" symbols are the results from both the $\mathrm{Cmn}$ and $\mathrm{Ccr}$, and the circles are results from water zones in the adjacent Nolichucky Shale (Cn) for comparison. The deeper $\mathrm{Cn}$ zones (GW-134-3,11,18) have $\delta^{18} \mathrm{O}<7$ per mil whereas the shallower zones (GW-134-25, 29,33) have $\delta^{18} \mathrm{O} \geq 7$ per mil perhaps suggesting longer residence times and differing amounts of water-rock interactions. The triangles represent the data for GW-734 and GW-722-32 and GW-722-33 which intersect cavities at the same elevations. No correlations of $\delta \mathrm{D}$ and $\delta^{18} \mathrm{O}$ with season sampled, geologic formation or water zone type (fracture cavity or water zone) are apparent from the data. However, there is a poor correlation $\left(\mathrm{R}^{2}=0.31\right)$ between $\delta \mathrm{D}$ and depth, with a slight increase in $\delta \mathrm{D}$ occurring with increasing depth $(\delta \mathrm{D}=0.0065$ (Depth) -36.28$)$. No similar trend with $\delta^{18} \mathrm{O}$ occurs $\left(\delta^{18} \mathrm{O}\right.$ 
$=-0.00013$ (Depth) $-7.13 ; R^{2}=0.02$ ). Fig. 2 shows that all samples are shifted relative to the World Meteoric Water Line (WMWL; Craig, 1961). Waters in other areas of the Oak Ridge Reservation (ORR) also exhibit similar characteristics (Dreier and Toran, 1989; D. Marsh, pers. comm., 1992).

The shifted stable isotope data likely reflect regional isotopic compositions indicative of source areas of the recharged precipitation. More isotopically depleted values are found with increasing distance from oceans, and in arctic air masses (Epstein and Mayeda, 1953; Friedman, 1953, Craig, 1963). Air masses moving from the gulf of Mexico northward to the continental U.S. are isotopically enriched compared with arctic air masses moving southward. Data compiled and contoured by Taylor (1974) show that an average $\delta \mathrm{D}$ in Tennessee is relatively enriched at $\approx-30$ per mil, similar to the average value of -33.3 per mil noted in Table 3 suggesting the dominant source of moisture which falls as precipitation and recharges local groundwaters is from the Gulf of Mexico. Unpublished studies by S. Lindberg show that the majority (285\%) of the moisture for local precipitation originates from the Gulf of Mexico, with only a small percent ( $515 \%)$ origination from the direction of the Atlantic Ocean (S. Lindberg, pers. comm., 1993).

The International Atomic Energy Agency (IAEA) reports $\delta^{18} \mathrm{O}$ and $\delta \mathrm{D}$ for three stations within the 30 per mil contour which may have similar stable isotope contents to those found in Tennessee. Stable isotope data (IAEA, 1969, 1970, 1971, 1973, 1979, 1983, 1986, 1990) from these stations (Veracruz, Mexico, Hatteras, NC, and Waco, TX) are plotted on Fig. 3. Data from San Juan, Puerto Rico is included for comparison because precipitation at this location must be dominated by isotopically enriched oceanic air masses.

The IAEA data is evaluated based on season. The number of data points from each station on Fig. 3 which have a $\delta D$ enriched (by greater than 1 per mil) relative to the WMWL were summed for the winter and summer months, and the percentage of data points which exhibit enriched $\delta \mathrm{D}$ calculated (Table 4). A total of $\approx 70 \%$ of the precipitation in the October to March season has had enriched $\delta \mathrm{D}$ at the listed stations between 1953 and 1987 , whereas $\approx 75 \%$ of the precipitation during the summer months is depleted in $\delta \mathrm{D}$ relative to the WMWL. Because the majority of the current recharge on the ORR occurs during the winter season (Moore and Toran, 1992, p 7), it is reasonable to expect that groundwaters would exhibit isotopic enrichment relative to the WMWL, as is observed in Fig. 2. Hence, the shifted isotopic compositions of the ORR waters reflect natural, regional isotopic compositions, rather than local effects.

In many cases, a local meteoric water line can be identified using groundwater data because groundwaters in porous media are often good integrators for the variable concentrations associated with different precipitation events and seasons. No consistent correlation $\left(\mathrm{R}^{2}=0.04 ; \delta \mathrm{D}=2.66 \delta^{18} \mathrm{O}-14.39\right)$ is identified by the samples (Table 3), showing that, either insufficient data have been obtained, or the flow system in the $\mathrm{Cmn}$ and $\mathrm{Ccr}$ is not a good integrator and may consist of some very quickflow zones where the $\delta \mathrm{D}$ and $\delta^{18} \mathrm{O}$ may closely approximate the compositions in individual precipitation events in which 
$\delta^{18} \mathrm{O}$ and $\delta \mathrm{D}$ can vary widely.

The large, mud filled cavity intersected by GW-734 (elevation $=255$ to $268.5 \mathrm{~m}$ ) occurs at approximately the same elevation as smaller cavities in GW-722-32 (elevation $=250$ to $261 \mathrm{~m}$ ) and GW-722-33 (elevation $=261.5$ to $265 \mathrm{~m}$ ). However, $\delta \mathrm{D}$ between the wells differs by up to 7 per mil (triangles on Fig. 2). The conduits in the two wells are located $45 \mathrm{~m}$ apart, and appear to be hydrologically connected based on cross borehole testing (Shevenell et al., in prep.). These wells also respond very rapidly (within a few hours) to precipitation. The $\delta \mathrm{D}$ values from the wells for two different dates likely show the isotopic signatures of two separate, poorly mixed, precipitation events. More frequently collected samples (ie. hourly during a storm) are required to more fully evaluate the timing of the link between precipitation and conduit waters.

$\delta^{13} \mathrm{C}$ data

Carbon-13 ( $\delta^{13} \mathrm{C}$, per mil PDB) values are also listed in Table 3. In order to evaluate the $\delta^{13} \mathrm{C}$ data, several models were used to calculate expected $\delta^{13} \mathrm{C}$ values given the known isotopic composition of the Cmn and Ccr and local vegetation. The isotopic composition of local carbonate rocks averages about -1 per mil (Foreman, 1991). Foreman (1991) reports $\delta^{13} \mathrm{C}$ for calcite and dolomite in the $\mathrm{Cn}$ as averaging -1.97 per mil $(n=6)$ and -0.84 per mil $(n=8)$, as well as whole rock $\delta^{13} \mathrm{C}$ for five $\mathrm{Cmn}$ samples $\left(\delta^{13} \mathrm{C} \approx+0.13 \mathrm{per} \mathrm{mil}\right)$. The average $\delta^{13} \mathrm{C}$ in leaves from 3 species located on ridges, slopes and riparian zones $(n=46)$ in a nearby valley (within $1 \mathrm{~km}$ ) in 1989 is $\approx-29$ per mil (Garten and Taylor, 1992). It is assumed that the same species dominate in $\mathrm{BCV}$. Soil $\mathrm{CO}_{2}$ is generally enriched in $\delta^{13} \mathrm{C}$ relative to the associated vegetation by about 5 per mil (Coleman and Fry, 1991), suggesting that $\delta^{13} \mathrm{C}-\mathrm{CO}_{2}$ in the soil is on the order of -25 per mil during the summer months. The samples collected by Garten and Taylor (1992) represent minimum values because they. are from leaves collected during the summer. Studies by Rightmire (1978) show that $\delta^{13} \mathrm{C}$ in $\mathrm{CO}_{2}$ soil gas varies with $\mathrm{P}_{\mathrm{CO} 2}$ and can be 10 to 12 per mil more enriched during the winter months. Hence, soil gases in the ORR area may have $\delta^{13} \mathrm{C}$ values between about -25 to -13 per mil, depending on the season.

The three models selected for simulating $\delta^{13} \mathrm{C}$ are (1) open system dissolution of calcium carbonate, (2) initial open system dissolution of calcium carbonate, followed by closed system dissolution (Salomons and Mook, 1980; referred to as Closed CaCO3 on Table 5), and (3) initial open system dissolution of calcite and dolomite, followed by closed system dissolution (Reardon and Fritz, 1978; referred to as Closed Cal/Dol on Table 5). Two separate sets of calculations are made for the open-closed system scenarios. The first calculation assumes all $\delta^{13} \mathrm{C}$ of carbonate rocks with which fluids interact have a value of -1 per mil which is the average of calcite and dolomite in the $\mathrm{Cn}$ and limestones of the $\mathrm{Cmn}$. The second set of calculations uses a whole rock $\mathrm{Cmn} \delta^{13} \mathrm{C}$ of 0.13 per mil for the calculations of closed system dissolution of $\mathrm{CaCO}_{3}$, and a $\delta^{13} \mathrm{C}_{\text {calcite }}$ of -1.97 per mil and $\delta^{13} \mathrm{C}_{\text {dolomite }}$ of -0.84 per mil for the openclosed system dissolution of calcite and dolomite. 
Table 5 compares the measured values with those of the different model results for estimated winter (recharge temperatures and fractionation factors for $5^{\circ} \mathrm{C}$ ) and summer (recharge temperatures and fractionation factors for $\left.25^{\circ} \mathrm{C}\right) \delta^{13} \mathrm{C}$ values in soil $\mathrm{CO}_{2}$. Calculated numbers in bold most closely match measured values. The \% error column identifies the error of the modeled versus the measured value. Similar results are obtained from the two calculations which assume different rock $\delta^{13} \mathrm{C}$, although slightly better matches are obtained with the second set of calculations.

None of the models described above suitably predicted the ${ }^{13} \mathrm{C}$ values for $\mathrm{GW}-131-28$, GW-135-03, or GW-135-11. All of these waters contain relatively high TDS (1200 to $10,000 \mathrm{mg} / \mathrm{L}$ ), and $\mathrm{SO}_{4}$ concentrations (700 to $1000 \mathrm{mg} / \mathrm{L}$ ), suggesting dissolution of gypsum along a flow path. The previous models are not appropriate for use in systems in which there has been significant gypsum dissolution (Reardon and Fritz, 1978). All three of these zones appear to sample waters which have relatively long residence times, and the GW-135-03 and GW-135-11 zones show some interaction with the underlying brine based on high $\mathrm{Cl}$ contents (up to $20,000 \mathrm{mg} / \mathrm{L}$ ). A final model was selected which is suitable for open-closed system dissolution of calcite, dolomite and gypsum (Reardon and Fritz, 1978), and these results are followed by an "*" in Table 5. The $\delta^{13} \mathrm{C}$ values in GW-131-28 and GW-135-11 are more closely predicted (within $3.9 \%$ and $12.1 \%$, respectively) with the model incorporating gypsum dissolution.

Zones GW-722-02, -06 and -20 are most closely matched with closed system dissolution of $\mathrm{CaCO}_{3}$ by water recharged during the winter months. The ${ }^{13} \mathrm{C}$ in GW-722-17, GW-722-33, GW-131-12, GW-135-30 and GW-722-30 suggests closed system dissolution of calcite and dolomite by water recharged during winter months. The fact that most of the zones (Table 5) suggest waters recharge the system during winter months is reasonable given that the majority of recharge to the system occurs in the winter months. Only one zone suggests closed system dissolution of carbonates by water recharged during summer months (GW-135-41). None of the zones sampled have $\delta^{13} \mathrm{C}$ values suggestive of open sys-

tem dissolution of calcite (Table 5). In addition, none of the waters containing ${ }^{13} \mathrm{C}$ data exhibited $\mathrm{P}_{\mathrm{CO}_{2}}$ near atmospheric which is reasonable given that all waters appear to have undergone closed system dissolution.

\section{DISCUSSION}

Although the quarterly monitoring data presented here are not the optimum type of data to use in the evaluation of karst aquifer behavior, useful information was obtained. Clearly, temporal data is mandatory in these systems in which water chemistry can vary rapidly in response to precipitation events. Frequent (daily, hourly) monitoring data allows for a more useful and definitive evaluation of a karst aquifer. However, when less frequent monitoring data are available, they should not be overlooked merely because the data type is not optimum for the study of the karst aquifer. This less frequent data is used here to help refine a conceptual model of flow through the karst aquifer at the Y-12 Plant. 
In order to develop a conceptual model of flow, it is necessary to map the distribution of quickflow (higher hydraulic conductivities), and slower flow zones. Table 6 lists parameters which are believed to be water zones which are subject to a component of quickflow. An " $X$ " in a column shows that the indicated variable is suggestive of a quickflow regime in the sampled interval of the well. An $X$ in the "SI(dol) Fluctuation" column indicates that the dolomite SI fluctuates between super- and undersaturation between sampling events. The $\mathrm{P}_{\mathrm{CO} 2}$ column is marked if the calculated $\mathrm{P}_{\mathrm{CO} 2}$ is near the atmospheric value $\left(-\log \left(\mathrm{P}_{\mathrm{CO} 2}\right)=3.5 \pm 0.3 \mathrm{~atm}\right)$. Consistent undersaturation with respect to calcite in all sampling events is noted by an $\mathrm{X}$ in the "Undersat wrt Calcite" column. If a well is known to be completed in a cavity, the appropriate column contains an $\mathrm{X}$. Finally, an $\mathrm{X}$ in the $\mathrm{CV}>0.10$ column indicates a CV of $>10 \%$ for the well water, which is indicative of quickflow.

Eighty-one wells listed in Table 6 are not noted as having been completed in a cavity. Forty-four of these wells have at least one geochemical parameter suggestive of quickflow indicating (1) poor records for the older wells may have omitted notations for cavities when they were actually present, (2) relatively quickflow may be associated with fractures in proximity to cavities. Note that recent plugging and abandonment activities of some of the older wells shows that records for many of these older wells are poor. Some records indicate incorrect completion depths, screened intervals, and even incorrect lithologies and formations in which the wells are completed (Jago, 1993, pers. comm.). Hence, the data presented here may suggest the presence of previously unknown cavities and fractures in these wells.

Seventy-one of the 99 (71.7\%) wells show at least one geochemical parameter suggestive of quickflow, 37 of which only have one such parameter. Twenty-three of the wells have 2 parameters suggestive of quickflow, whereas 10 wells show 3 parameters. Hence, relatively few wells have multiple indications of quickflow. Only one (GW-722-32) of the 18 zones noted to have a cavity in the completion zone showed no geochemical parameters indicative of quickflow, likely because this zone has only been sampled once and data on the fluctuation in dolomite SI and the CV are not available. Not many water zones (16.7\%) have $\mathrm{P}_{\mathrm{CO} 2}$ near atmospheric, which is not surprising considering that even very short residence time in the root zone will likely increase $\mathrm{P}_{\mathrm{CO} 2}$ above atmospheric.

Using Table 6, the results of the previous sections, locations of sinkholes, identification of cavities in other wells (Jones et al., 1992; Shevenell, 1994), and locations and interconnections between cavities noted during drilling and purging of the wells (Shevenell et al., 1992), maps are constructed noting the probable (2-D) locations of quickflow zones (ie. high hydraulic conductivity and specific discharge). Fig. 4 is a base map showing the locations of the more detailed cavity maps from east to west (Maps 1 through 6) which were constructed to visualize conduit locations. Three of the 6 maps are shaded in Fig. 4, and these three maps are included here (Figs. 5 through 7). The remaining three maps can be found in Shevenell (1994). Fig. 8 identifies the symbols on Figs. 5 through 7. Geologic contacts on these figures are based on the geologic map of Hatcher et al (1992), and the contacts identified during drilling the Cmn exit pathway pickets (Shevenell et al., 1992). Conduits connecting individual wells are inferred and based 
on several assumptions believed to be realistic at this site. It is assumed that the dominant flow direction in the Cmn is strike-parallel, with localized strike-perpendicular solution enlarged zones feeding into the main conduit system in the valley. Piezometric surface maps (HSW, 1992a, 1992b) support the assumption that groundwater flow is from the ridges toward the valley, with strike-parallel flow dominating in the $\mathrm{Cmn}$ in BCV. Strike parallel flow is also supported by the presence of contaminants in numerous Cmn wells (HSW, 1991a, 1992a; Shevenell, 1994). For instance, $\mathrm{NO}_{3}$ contamination at Picket A (GW-683 and GW-684) shows that contaminants have migrated nearly $3,350 \mathrm{~m}$ along strike from the source area at the S-3 Ponds. Cavities in the Ccr are assumed to feed into the Cmn. Where no data are available, it is assumed that the $\mathrm{Ccr}$ feeder conduits mimic the surface drainages, following the trend of tributary streams.

Based on a number of observations, the cavities in the Cmn appear to be maze passages (White, 1988), probably with an anastomosing pattern based on the following information obtained during drilling of some Cmn wells. During drilling of both GW-683 (depth 45.4 to $48.2 \mathrm{~m}$ ) and GW-684 (depth = 37.2 to $37.8 \mathrm{~m}$; Picket A), increased turbidity in spring SS-5 was observed. This spring is located $\approx 130 \mathrm{~m}$ north of GW-683, and $\approx 30 \mathrm{~m}$ north of GW-684. Apparently there are fractures connecting the Ccr and $\mathrm{Cmn}$ in this location (Shevenell et al., 1992). One well in Picket C (GW-738) was found to have a natural hydraulic connection to the surface. During drilling at depths $>17 \mathrm{~m}$, water and air emerged at the surface in old Bear Creek Road $\approx 3$ to $6 \mathrm{~m}$ south of the drilling rig.

In several cases, wells could not be completed past a shallow, cavernous zone due to excess water production and caving of the well bore. For instance, the first two attempts to complete GW-705 (Picket B; Figs. 1 and 7) to the target depth failed. The two initial wells were located along strike from one another, and the third, successful, attempt was sited $17 \mathrm{~m}$ south of the first two wells in order to displace it from the along strike cavity zone intersected by the first two wells. Three attempts were also required to complete GW-724 (Picket C). During drilling of the second well, return water was lost, and was found to be emerging in the first well; ultimately both of the wells had to be plugged and abandoned. Significant difficulties in completing GW-728 (south of the Burial Grounds) required attempts to seal a series of small cavities at 32 to $41.5 \mathrm{~m}$, and a large cavity at 49.7 to $52.1 \mathrm{~m}$, with bentonite and grout and case off the cavernous zones. During drilling of GW-790 (located $\approx 30 \mathrm{~m}$ south of GW-728) one to two months later, bentonite and grout from GW-728 were encountered in two separate cavernous zones at about 36.6 and $64.6 \mathrm{~m}$ depth (R. Dreier, pers. comm., 1993). In summary, numerous examples exist which suggest that the conduit system in the Cmn is well interconnected, either honeycombed or anastomosing, and where sufficient data are available, the maps of Figs. 5 through 7 reflect this.

In locations which contain a large number of wells in a relatively small area (see Map 2, Fig. 6, in the Y-12 Plant area), the cavity system appears to be a complicated, anastomosing network of cavities. Note that the maps are drawn assuming cavities in nearby wells are interconnected. It is certainly possible that the connections shown on the maps are not accurate and that the noted cavities may be in direct 
hydrologic communication with other, undiscovered cavities. However, it is the opinion of the author that the conduit network is considerably more complicated than that shown in Figs. 5 through 7, and that the maps represent a very simplistic, first approximation to the distribution of cavities at this site.

\section{CONCLUSIONS}

Use of quarterly monitoring data to evaluate quickflow behavior in a karst aquifer was inconclusive in some cases, yet provided considerable useful information for many water zones tapped by wells. Although quarterly geochemical monitoring data is not optimum for use in evaluating karst aquifer behavior, it should not be discounted if it is available because it can be very useful in the identification of zones subjected to quickflow. Water zones in wells at the Y-12 Plant which exhibit quickflow behavior were identified based on their geochemical characteristics and variability in geochemical parameters, and observations made during drilling of the wells. Generalized maps of the inferred distribution of quickflow regimes in the Car and $\mathrm{Cmn}$ were constructed based on the chemical characteristics of the waters. The maps are a first approximation to the distribution of quickflow zones, and additional studies are planned which may help to refine the interpretations made from the chemical analyses of waters in these karst aquifers. The preliminary data suggest that the $\mathrm{Cmn}$ is composed of a complicated network, of interconnected, perhaps anastomosing, cavities. The degree of interconnection between the identified cavities is yet to be determined, although it is expected that there is significant vertical and lateral interccmection between the cavities located throughout $\mathrm{BCV}$ which is underlain by the Cmn. Generally, groundwater flows from the $\mathrm{Ccr}$ to the $\mathrm{Cmn}$, except near Picket $A$ where there is evidence from $\mathrm{NO}_{3}$ and $\mathrm{a}_{\mathrm{Mg}} / \mathrm{a}_{\mathrm{Ca}}$ data which suggest groundwater flow from the $\mathrm{Cmn}$ into the $\mathrm{Ccr}$. As is typical in other karst settings, a significant quickflow component through fractures and cavities can be identified within portions of the aquifer, whereas other portions of the aquifer are typified by slowly flowing (matrix intervals), long residence time waters.

Acknowledgments-- The author thanks Lee Cooper (Oak Ridge National Laboratory) and Claudia Mora (University of Tennessee) for providing the $\delta \mathrm{D}, \delta^{18} \mathrm{O}$, and $\delta^{13} \mathrm{C}$ analyses, and D.K. Solomon and C.T. Rightmire for providing review comments on an early version of the manuscript.

\section{REFERENCES}

Back, W. and Zoetl, J. (1975) Application of geochemical principles, isotopic methodology, and artificial tracers to karst hydrology. In Hydrogeology of Karstic Terrains, International Association of Hydrogeologists, Chapter IX. 105-121.

Bassett, J.L. and Ruhe, R.V. (1973) Fluvial geomorphology in karst terrain. In Fluvial Geomorphology (ed Marie Morrisawa), pp. 75-89. State University of New York at Binghamton. 
Boynton, D. and Reuther, W. (1938) A way of sampling soil gases in dense subsoil and some of its advantages and limitations. Soil Sci. Soc. Am. Proc. 3,37-42.

Busenberg, B. and Plummer, L.N. (1982) The kinetics of dissolution of dolomite in $\mathrm{CO}_{2}-\mathrm{H}_{2} \mathrm{O}$ systems at 1.5 to $65 /(\mathrm{deC}$ and 0 to 1 ATM P $\mathrm{CO2}$. Am. J. of Sci. $282,45-78$.

Coleman, D.C. and Fry, B. (1991) Carbon Isotope Techniques. 274 pp. Academic Press.

Craig, H. (1961) Isotopic variations in meteoric waters. Science 133, 1702-1703.

Craig, H. (1963) The isotopic geochemistry of water and carbon in geothermal areas. In Nuclear geology on geothermal areas, Spoleto: Pisa, Consiglio Nazionale della Ricerche, Laboratorio de Geologia Nucleare. (ed E. Tongiorgi), 17-53.

Dreier, R.B. and Toran, L.E. (1989) Hydrogeology of Melton Valley determined from hydraulic head measuring station data. ORNL/TM-1126.

Dreier, R.B., Early, T.O., and King, H.L. (1993) Results and interpretation of groundwater data obtained from multiport-instrumented coreholes (GW-131 through GW-135), Fiscal Years 1990 and 1991. Y-12 Plant report Y/TS-803.

Dreier, R.B. (1993) personal communication, Environmental Sciences Division, Oak Ridge National Laboratory.

Drever, J.I. (1988) The Geochemistry of Natural Waters. 437 pp. Prentice Hall, Englewood Cliffs, New Jersey.

Epstein, S. and Mayeda, T. (1953) Variation of $\mathrm{O}^{18}$ content o waters from natural sources. Geochim. et Cosmochim. Acta 4, 213-224.

Ford, D.C. and Ewers, R.O. (1978) The development of limestone cave systems in the dimensions of length and depth. Can.J. Earth. Sci. 15, 1783-1798.

Foreman, J.L. (1991) Petrologic and geochemical evidence for water-rock interaction in the mixed carbonate-siliciclastic Nolichucky Shale (Upper Cambrian) in East Tennessee. Ph.D. Dissertation, University of Tennessee, Knoxville.

Friedman, 1. (1953) Deuterium content of natural water and other substances. Geochim. Cosmochim. Acta 4, 89-103. 
Garten Jr., C.T. and Taylor, Jr., G.E., (1992) Foliar $\delta^{13} \mathrm{C}$ within a temperate deciduous forest: spatial, temporal, and species sources of variation. Oecologia 90, 1-7.

Goldstrand, P.M. (in press), Stratigraphic variations and secondary porosity within the Maynardville Limestone in Bear Creek Valley, Y-12 Plant, Oak Ridge, Tennessee. Y-12 Plant report Y/TS-1093.

Goldstrand, P.M., Dreier, R.B., and Menefee, L. (in prep.). Porosity development in the Copper Ridge Dolomite and Maynardville Limestone, Bear Creek Valley, Tennessee, Y-12 Report.

Haase, C.S. (1991) Geochemical identification of ground-water flow systems in fractured bedrock near Oak Ridge, Tennessee. In Proceedings of the FOCUS conference on Eastern Ground-water Issues, October 29-31, 1991, Portland, Maine, pp. 275-288. National Water Well Association.

Hatcher Jr., R.D., Lemiszki, P.J., Dreier, R.B., Ketelle, R.H., Lee, R.R., Lietzke, D.A., McMaster, W.M., Foreman, J.L., and Lee, S.Y. (1992) Status report on the geology of the Oak Ridge Reservation. ORNL/TM-12074.

Hicks, D.S., Solomon, D.K., and Farrow, N.D. (1992) Investigation of groundwater flow zones and contaminant transport in Solid Waste Storage Area 5 at Oak Ridge National Laboratory, Oak Ridge, Tennessee. ORNL/ER-154.

HSW, Environmental Consultants, Inc. (1991a) Groundwater quality assessment for the Bear Creek hydrogeologic regime at the Y-12 Plant: 1991 Groundwater quality data and calculated rate of contaminant migration. Y/SUB/91-YP507C/1/1.

HSW, Environmental Consultants, Inc. (1991b) Groundwater quality assessment for the Upper East Fork Poplar Creek hydrogeologic regime at the Y-12 Plant: 1991 Groundwater quality data and calculated rate of contaminant migration. Y/SUB/91-YP507C/2/1.

HSW, Environmental Consultants, Inc. (1991c) Groundwater quality assessment for the Chestnut Ridge hydrogeologic regime at the Y-12 Plant: 1991 Groundwater quality data and calculated rate of contaminant migration. Y/SUB/91-YP507C/3/1.

HSW, Environmental Consultants, Inc. (1992a) Groundwater quality assessment for the Bear Creek hydrogeologic regime at the Y-12 Plant: 1992 Groundwater quality data and calculated rate of contaminant migration. Y/SUB/92-YP507C/1/1. 
HSW, Environmental Consultants, Inc. (1992b) Groundwater quality assessment for the Upper East Fork Poplar Creek hydrogeologic regime at the Y-12 Plant: 1992 Groundwater quality data and calculated rate of contaminant migration. Y/SUB/92-YP507C/2/1.

HSW, Environmental Consultants, Inc. (1992c) Groundwater quality assessment for the Chestmut Ridge hydrogeologic regime at the Y-12 Plant: 1992 Groundwater quality data and calculated rate of contaminant migration. Y/SUB/92-YP507C/3/1.

International Atomic Energy Agency (IAEA) (1969) Technical report series No. 96, Environmental isotope data No. 1: World survey of isotope concentration in precipitation (1953-1963), Vienna.

International Atomic Energy Agency (IAEA) (1970) Technical report series No. 117, Environmental isotope data No. 2: World survey of isotope concentration in precipitation (1964-1965), Vienna.

International Atomic Energy Agency (IAEA) (1971) Technical report series No. 129, Environmental isotope data No. 3: World survey of isotope concentration in precipitation (1966-1967), Vienna.

International Atomic Energy Agency (IAEA) (1973) Technical report series No. 147, Environmental isotope data No. 4: World survey of isotope concentration in precipitation (1968-1969), Vienna.

International Atomic Energy Agency (IAEA) (1979) Technical report series No. 192, Environmental isotope data No. 6: World survey of isotope concentration in precipitation (1972-1975), Vienna.

International Atomic Energy Agency (IAEA) (1983) Technical report series No. 226, Environmental isotope data No. 7: World survey of isotope concentration in precipitation (1976-1979), Vienna.

International Atomic Energy Agency-(IAEA) (1986) Technical report series No. 264, Environmental isotope data No. 8: World survey of isotope concentration in precipitation (1980-1983), Vienna.

International Atomic Energy Agency (IAEA) (1990) Technical report series No. 311, Environmental isotope data No. 9: World survey of isotope concentration in precipitation (1984-1987), Vienna.

Jago, W.K. (1993) personal communication, Y-12 Plant, Oak Ridge, Tennessee.

Jones, S.B., Harrington, B.K., and Fields, S.M. (1992) Updated subsurface data base for Bear Creek Valley, Chestnut Ridge, and parts of Bethel Valley on the U.S. Department of Energy Oak Ridge Reservation. Y-12 Plant report Y/TS-881. 
Kharaka, Y.K, Gunter, W.D., Aggarwal, P.K., Perkins, E.H., and DeBraal, J.D: (1988) SOLMINEQ.88: A computer program for geochemical modeling of water-rock interactions. U.S. Geol. Survey Water-Resources Investigations Report 88-4227, 420 pp.

King, H.L. and Haase, C.S. (1988) Summary of results and preliminary interpretation of hydrogeologic packer testing in core holes Well GW-131 through GW-135 and CH-157, Oak Ridge Y-12 Plant. Y-12 Plant report Y/TS-495.

Langmuir, D. (1971) The geochemistry of some carbonate ground waters in Central Pennsylvania. Geochim. Cosmochim. Acta 35, 1023-1045.

Lindberg. S. (1993) personal communication, Environmental Sciences Division, Oak Ridge National Laboratory.

Mahler. B. and Bennett. P. (1991) The interaction of flow mechanics and aqueous chemistry in a Texas hill country grotto. In Proceedings of the Third conference on hydrogeology, ecology, monitoring, and management of ground water in karst terranes, pp. 405-416. U.S. EPA and the Association of Ground Water Scientists and Engineers.

Marsh. D. (1992) personal communication, Environmental Sciences Division, Oak Ridge National Laboratory.

Moore, G.K. and Toran. L.E. (1992) Supplement to a hydrologic framework for the Oak Ridge Reservation. Oak Ridge, Tennessee. ORNL/TM-12191.

Pitty, A.F. (1968) Calcium carbonate content of karst water in relation to flow-through time. Narure 217, 939-940.

Pitty. A.F. (1971) Rate of uptake of calcium carbonate in underground karst water. Geol. Mag. 108, 537-543.

Reardon, E.J. and Fritz. P. (1978) Computer modeling of groundwater ${ }^{13} \mathrm{C}$ and ${ }^{14} \mathrm{C}$ isotope compositions. J. Hydrol. 36, 201-224. 
Rightmire, C.T. (1978) Seasonal variation in $\mathrm{P}_{\mathrm{CO} 2}$ and ${ }^{13} \mathrm{C}$ content of soil atmosphere. Water Resour. Res. 14(4), 691-692.

Russell, E.J. and Appleyard, A. (1915) The atmosphere of the soil, its composition and causes of variation. J. Agr. Sci. 7, 1-48.

Salomons, W. and Mook, W.G. (1980) Isotope geochemistry of carbonates in the weathering zone, Chapter 6. In Stable Isotope Geochemistry (ed J. Hoefs), pp 239-269. Springer-Verlag, Berlin,

Shevenell, L., McMaster, B., and Desmarais, K. (in prep.), Evaluation of cross borehole tests at selected wells in the Maynardville Limestone and Copper Ridge Dolomite at the Oak Ridge Y-12 Plant. Y-12 Plant report Y/TS-1166.

Shevenell, L. and Beauchamp, J.J. (1994) Evaluation of cavity occurrence in the Maynardville Limestone and the Copper Ridge Dolomite at the Y-12 Plant using logistic and general linear models. Y-12 Plant report Y/TS-1022.

Shevenell, L. (1994) Chemical characteristics of waters in karst formations at the Oak Ridge Y-12 Plant. Y-12 Plant report Y/TS-1001.

Shevenell, L., Moore, G.K., and Dreier, R.B. (1994) Contaminant spread and flushing in fractured rocks at the S-3 Ponds site, Oak Ridge, TN. Ground Water Monitoring and Remediation XIV(2), 120-129.

Shevenell, L. and Dreier, R.B. unpublished chemical data from multiport monitoring wells.

Shevenell, L., Dreier, R.B., and Jago, W.K. (1992) Summary of fiscal years 1991 and 1992 construction, hydrologic and geologic data obtained from the Maynardville Limestone exit pathway monitoring program. Y-12 Plant report Y/TS-814.

Taylor, Jr., H.P. (1974) The application of oxygen and hydrogen isotope studies to problems of hydrothermal alteration and ore deposition. Econ. Geol. 69, 843-883.

Ternan, J.L. (1972) Comments on the use of calcium hardness variability index in the study of carbonate aquifers: With reference to the Central Pennines, England. J. Hydrol. 16, 317-321.

Thompson, B.K. (1993) Data base dictionary for the Oak Ridge Reservation hydrology and geology study groundwater data base. ORNL/TM-11909. 
White, W.B. (1988) Geomorphology and Hydrology of Karst Terrains. 464 pp. Oxford University Press, New York and Oxford.

Worthington, S.R.H. (1991) Karst hydrogeology of the Canadian Rocky Mountains. PhD dissertation, McMaster University, 227 pp. 


\section{LIST OF FIGURES}

Fig. 1. Generalized geologic map showing the approximate locations of the Maynardville Limestone Picket well transects (W, A, B, C, and J). Modified from Hatcher, et al. (1992).

Fig. 2. Deuterium versus oxygen-18 in wells at the $Y-12$ Plant.

Fig. 3. Deuterium versus oxygen-18 for four stations between 1953 and 1987.

Fig. 4. Base map showing the locations of the more detailed maps in Figs. 6 through 8.

Fig. 5. Location of cavities, Map 1.

Fig. 6. Location of cavities, Map 2.

Fig. 7. Location of cavities, Map 5.

Fig. 8. Symbols used in Figs. 6 through 8. 


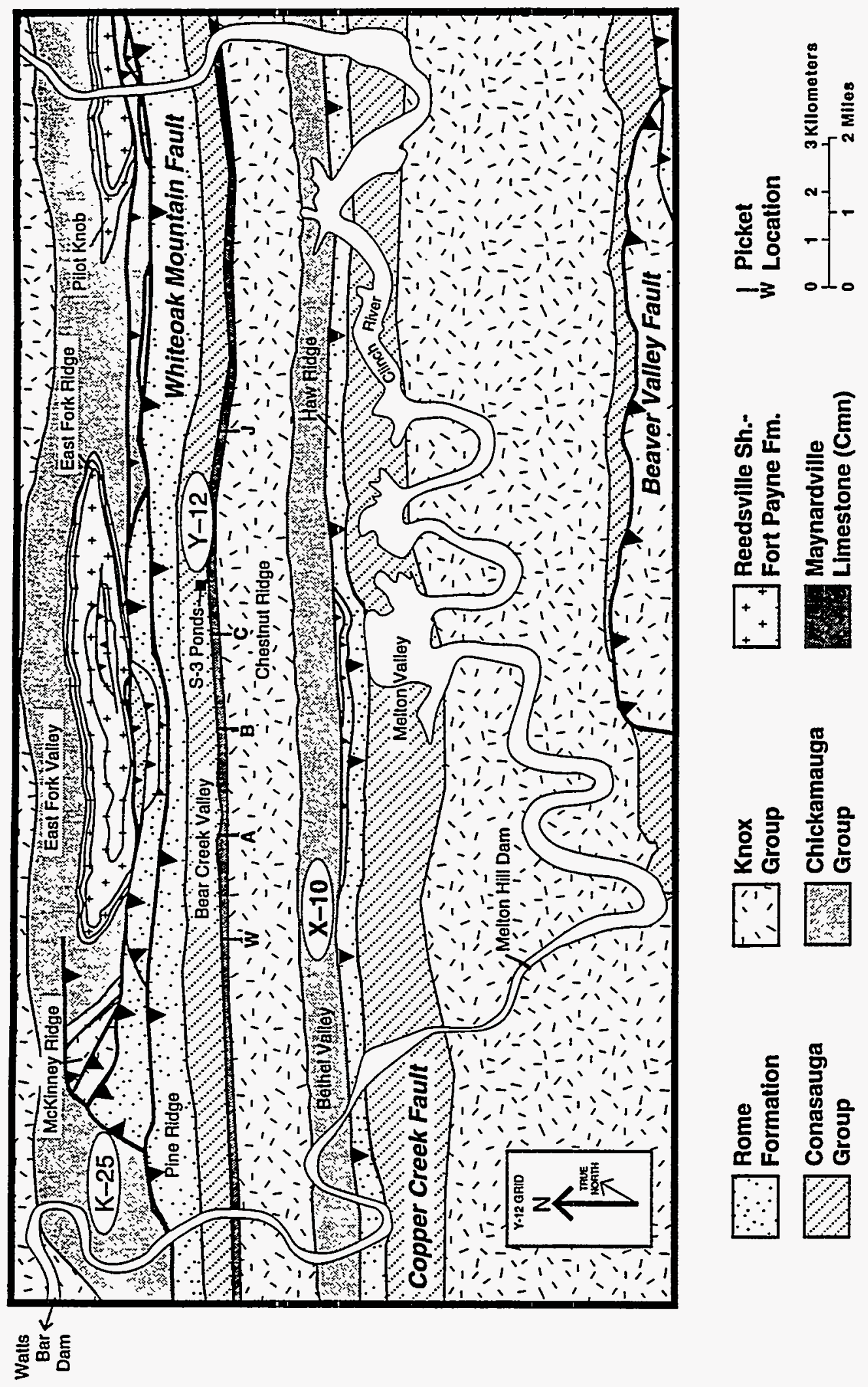




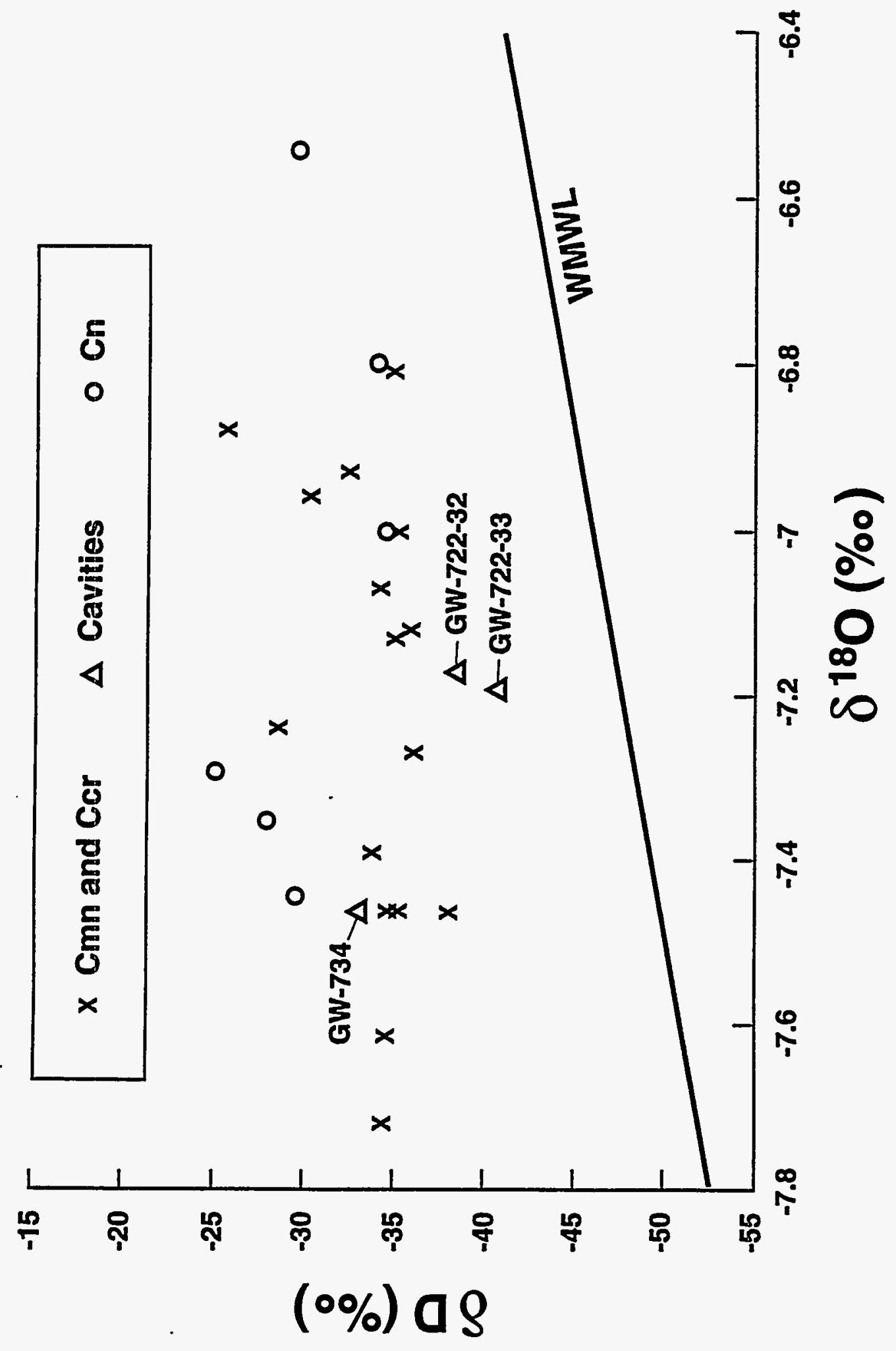

is 


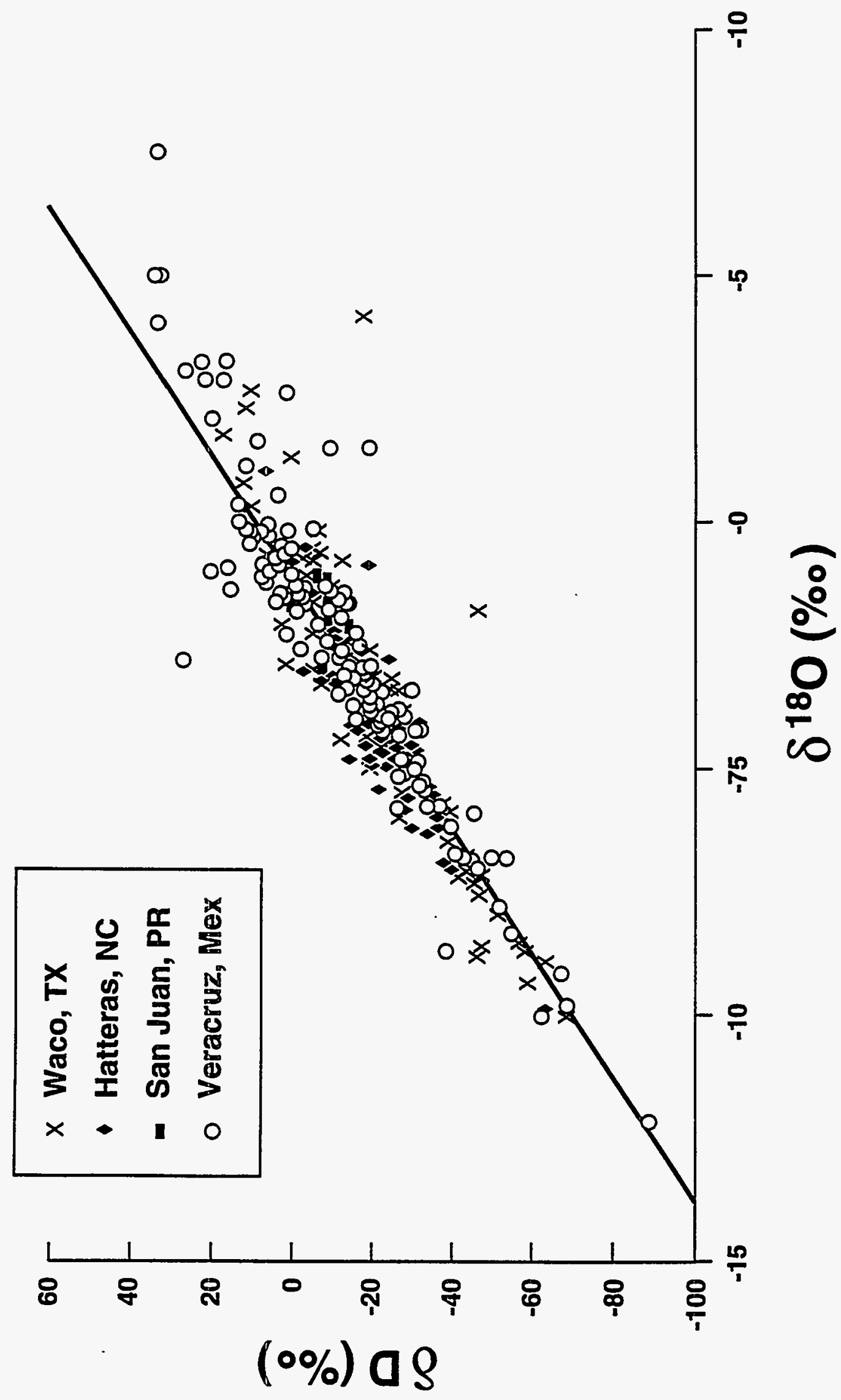




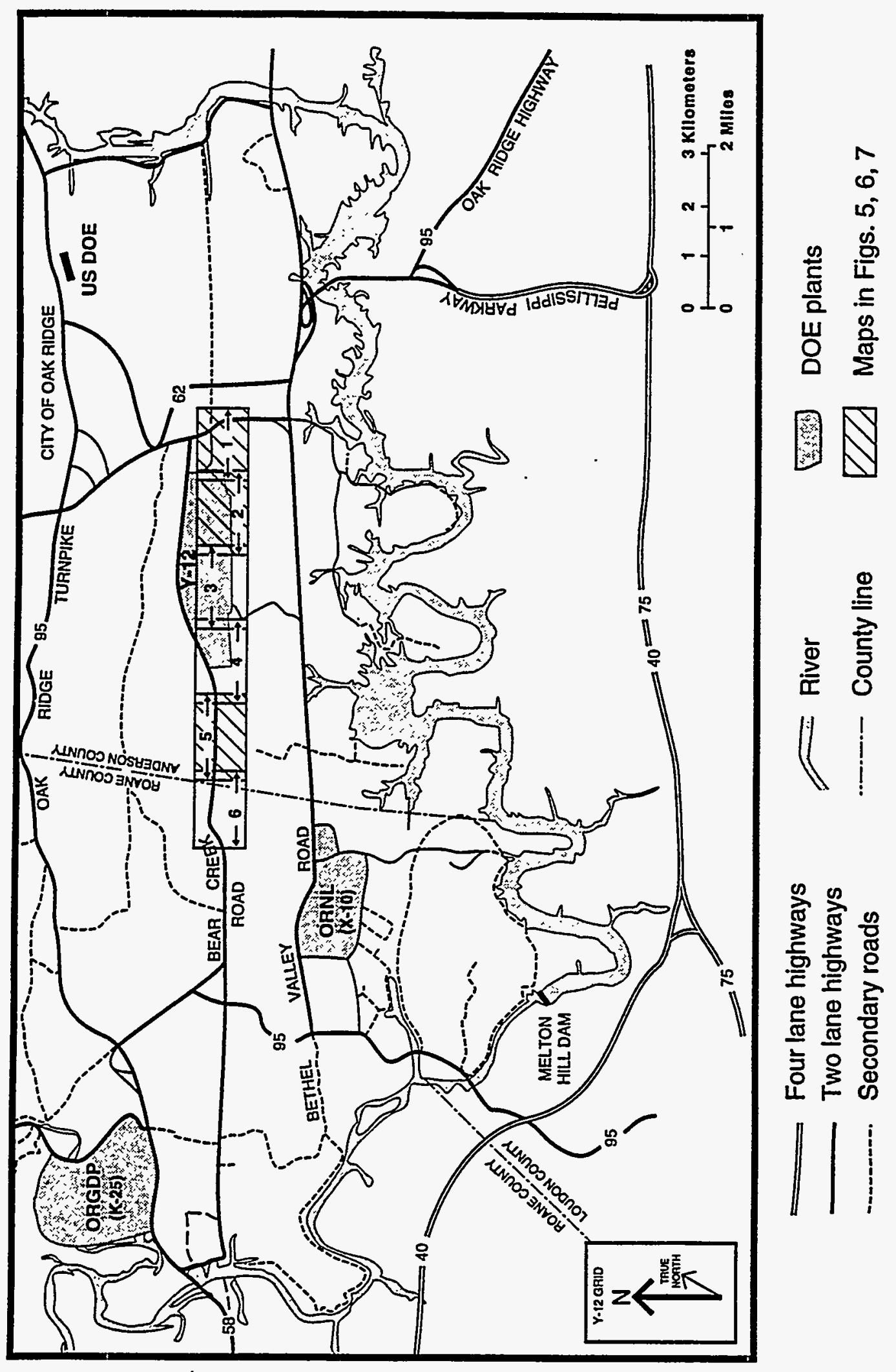




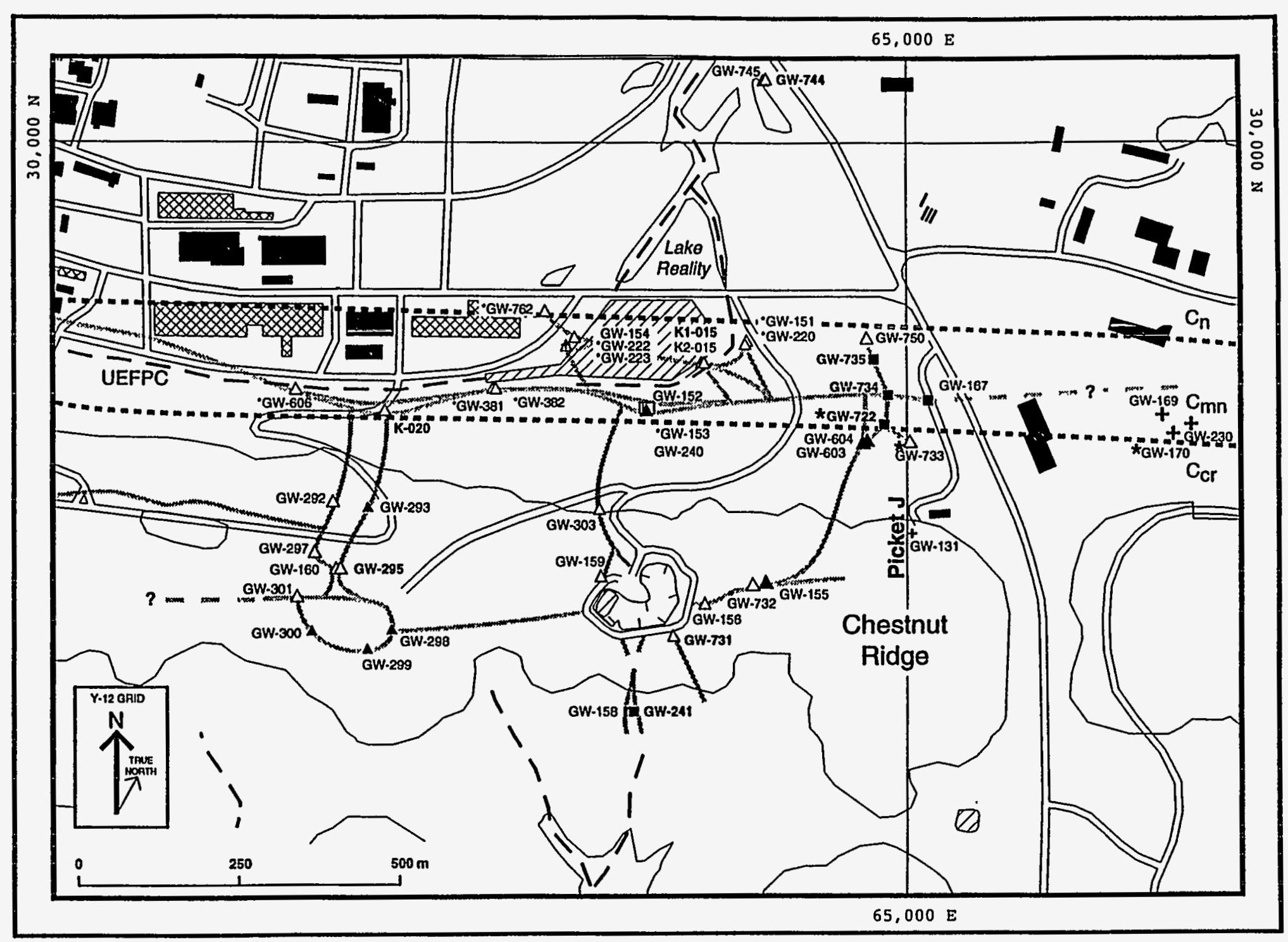

Fig. 5. 


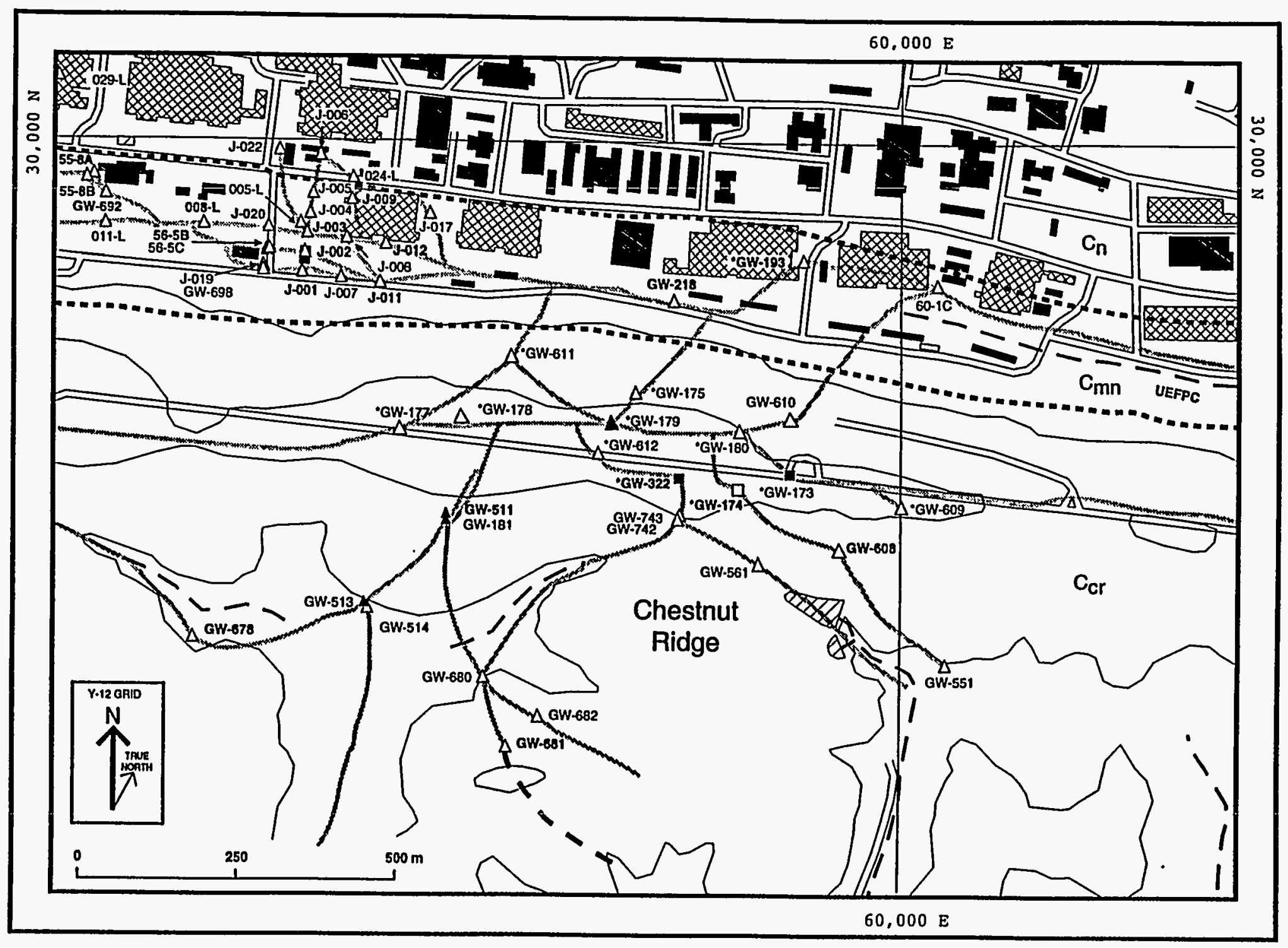

Fig. 6. 


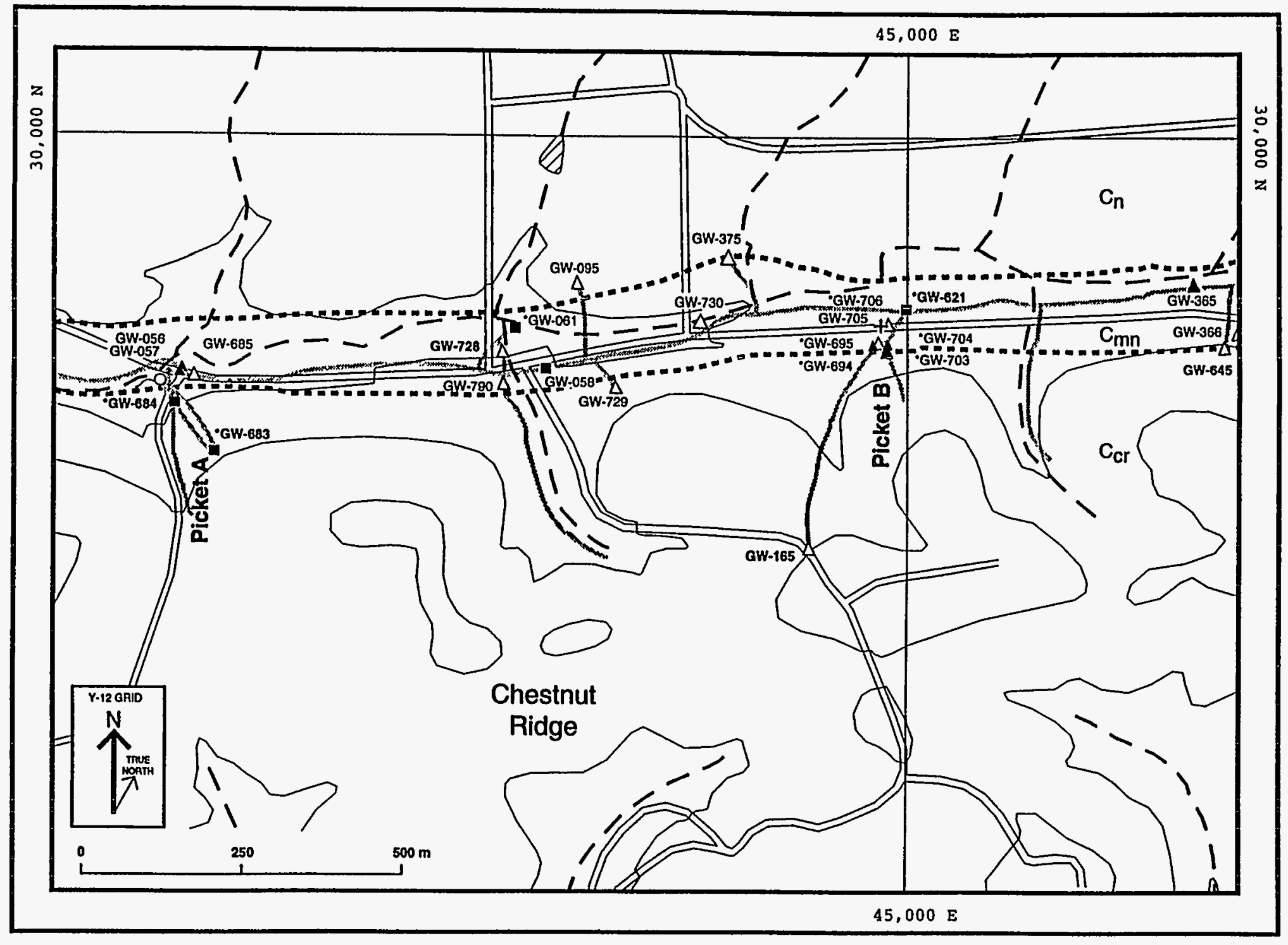

Fig. 7. 


\section{LEGEND}

+ Well location

$\triangle$ Cavity intersected by well;

no geochemical data substantiating quick flow

$\triangle$ Possible quick flow;

1 or 2 geochemical parameters suggest quick flow

$\square$ Probable quick flow;

3 or $\mathbf{4}$ geochemical parameters suggest quick flow

Cavity in completion interval;

1 to 4 geochemical parameters suggest quick flow

- Inferred position of conduits

- - Stream

Spring

........ Geologic contact

Buildings

$\Longrightarrow$ Contour line

= Road

GW-731 Well completed in a cavity

-GW.683 Contaminants have been detected in this well

Fig. 8. 
Table 1. Calcite and dolomite saturation indices.

\begin{tabular}{|c|c|c|c|c|c|c|c|}
\hline & \# Values & $\begin{array}{l}\text { SI(ฒal) } \\
\text { Min. }\end{array}$ & $\begin{array}{l}\text { SI(cal) } \\
\text { Max. }\end{array}$ & $\begin{array}{l}\text { SI(dol) } \\
\text { Min. }\end{array}$ & $\begin{array}{l}\text { SI(dol) } \\
\text { Max. }\end{array}$ & $\begin{array}{l}\text { SI(cal) } \\
\text { Min-Max }\end{array}$ & $\begin{array}{c}\text { SI(dol) } \\
\text { Min-Max }\end{array}$ \\
\hline 1090-F & 10 & -0.884 & 0.240 & -1.703 & 0.518 & -1.12 & -222 \\
\hline $1090-U$ & 8 & -0.877 & -0.017 & -1.703 & 0.018 & -0.86 & -1.72 \\
\hline GW-056-F & 4 & -0.334 & 0.800 & -0.896 & 1.378 & -1.13 & -2.27 \\
\hline GW-056-U & 5 & -1.195 & 0.826 & -2.644 & 1.447 & -2.02 & -4.09 \\
\hline GW-057-F & 2 & -0.204 & -0.117 & -0.864 & -0.677 & -0.09 & -0.19 \\
\hline GW-057-U & 2 & -0.213 & -0.121 & -0.872 & -0.707 & -0.09 & -0.17 \\
\hline$G W-058-F$ & 5 & -0.252 & 0.823 & -0.695 & 1.511 & -1.08 & -2.21 \\
\hline GW-058-U & 4 & -0.265 & 0.831 & -0.700 & 1.520 & -1.10 & -2.24 \\
\hline$G W-061-F$ & 4 & -0.463 & 0.673 & -1.562 & 0.722 & -1.14 & -2.28 \\
\hline GW-061-U & 4 & -0.453 & 0.667 & -1550 & 0.607 & -1.12 & -2.25 \\
\hline GW-064-F & 4 & -0.062 & 0.968 & -0.728 & 1334 & -1.03 & -2.06 \\
\hline GW-064-U & 5 & -0.082 & 0.966 & -0.738 & 1356 & -1.05 & -2.09 \\
\hline GW-099-F & 2 & -0.531 & 1245 & -1.032 & 2495 & -1.78 & 3.53 \\
\hline GW-099-U & 2 & -0.530 & 1254 & .1 .057 & 2528 & -1.78 & -3.59 \\
\hline GW-131-04-F & 1 & 0.313 & & 0.713 & & & \\
\hline GW-131-08-F & 1 & 0.077 & & 0.194 & & & \\
\hline GW-131-12-F & 1 & -0.040 & & -0.034 & & & \\
\hline GW-131-15-F & 1 & 0.522 & & 1.064 & & & \\
\hline$G W-131-24-F$ & 1 & 0.416 & & 0.867 & & & \\
\hline$G W-131-28-F$ & 1 & 0.480 & & 1.010 & & & \\
\hline GW-131-32-F & 1 & 0.267 & & 0.518 & & & \\
\hline GW-135-03-F & 4 & -1.261 & 0.593 & -2.660 & 1.07 & -1.85 & -3.73 \\
\hline GW-135-06-F & 1 & 0.453 & & 0.671 & & & \\
\hline$G W-135-11-F$ & 1 & 0.429 & & 0.638 & & & \\
\hline GW-135-19-F & 1 & 0.381 & & 0.716 & & & \\
\hline$G W-135-23-F$ & 1 & 0.867 & & 1.370 & & & \\
\hline GW-135-30-F & 2 & -0.656 & 0.690 & -1.292 & $1 A 36$ & -1.35 & -2.73 \\
\hline$G W-135-34-F$ & 1 & 0.566 & & 1.169 & & & \\
\hline GW-135-39-F & 1 & 0.235 & & 0.495 & & & \\
\hline$G W-141-F$ & 20 & -0.61 & 0.555 & -1.192 & 1.146 & -1.19 & -2.34 \\
\hline$G W-141-U$ & 20 & -0.629 & 0.554 & -1.186 & 1.143 & -1.18 & -2.33 \\
\hline GW-151-F & 8 & -0.413 & 0.617 & -1.120 & 7.132 & -1.03 & -2.25 \\
\hline GW-151-U & 6 & -0.413 & 0.617 & -1.120 & 1.132 & -1.03 & -2.25 \\
\hline GW-152-F & 12 & -0.946 & 0.781 & -2.080 & 1234 & -1.73 & -3.36 \\
\hline GW-152-U & 14 & -0.935 & 0.835 & -2.070 & 1.420 & -1.77 & -3.49 \\
\hline GW-153-F & 16 & -0.653 & 0.848 & -1.497 & 1.746 & -1.51 & 3.18 \\
\hline GW-153-U* & 18 & -0.539 & 1.011 & -1.187 & 1.957 & -1.55 & -3.14 \\
\hline$G W-154-F^{*}$ & 2 & 0.331 & 0.812 & 0.148 & 1.105 & -0.48 & -0.96 \\
\hline GW-154-U & 4 & -0.929 & 0.868 & -2.566 & 1.170 & -1.80 & 3.74 \\
\hline GW-155-F & 11 & -0.805 & 0.229 & -1.561 & 0.461 & -1.03 & -2.02 \\
\hline GW-155-U & 5 & -0.767 & -0.188 & -1.480 & -0.364 & -0.58 & -1.12 \\
\hline GW-158-F & 8 & -0.727 & 0.829 & -1.217 & 2323 & -1.56 & -3.54 \\
\hline GW-158-U & 9 & -0.836 & 0.831 & -1.512 & 2335 & -1.67 & 3.85 \\
\hline GW-167-F & 3 & -2.181 & 0.602 & -6.688 & 0.200 & -2.78 & -5.89 \\
\hline GW-167-U & 1 & 0.627 & & 0.225 & & & \\
\hline GW-173-F* & 10 & -0.794 & 1.110 & -1.578 & 2318 & -1.90 & 3.90 \\
\hline GW-173-U* & 6 & -0.773 & 1.162 & -1.511 & 2327 & -1.94 & 3.84 \\
\hline GW-174-F* & 8 & -0.113 & 1.394 & -0.235 & 2880 & -1.51 & 3.12 \\
\hline GW-174-U* & 6 & -0.094 & 1.417 & -0.206 & 2926 & -1.51 & -3.13 \\
\hline GW-179-F & 4 & -0.173 & 0.948 & -0.416 & 1908 & -1.12 & -2.32 \\
\hline$G W-181-F$ & 9 & -0.831 & 0.176 & -1.643 & 0.357 & -1.01 & -2.00 \\
\hline$G W \cdot 181-U$ & 9 & -0.817 & 0.164 & -1.630 & 0.346 & -0.98 & -1.98 \\
\hline GW-220-F & 5 & -0.264 & 0.688 & -0.738 & 1.192 & -0.95 & -1.93 \\
\hline GW-220-U & 4 & -0.287 & 0.704 & -0.775 & 12223 & -0.99 & -2.00 \\
\hline GW-221-F & 8 & -0.769 & 0.456 & -1.484 & 0.994 & -1.23 & -2.48 \\
\hline
\end{tabular}




\begin{tabular}{|c|c|c|c|c|c|c|c|}
\hline & \# Values & $\begin{array}{l}\text { SI(cal) } \\
\text { Min. }\end{array}$ & $\begin{array}{l}\text { SI(ळ) } \\
\text { Max. }\end{array}$ & $\begin{array}{l}\text { SI(dol) } \\
\text { Min. }\end{array}$ & $\begin{array}{l}\text { SI(dol) } \\
\text { Max. }\end{array}$ & $\begin{array}{l}\text { SI(cal) } \\
\text { Mir-Max }\end{array}$ & $\begin{array}{l}\text { SI(dol) } \\
\text { Min-Max }\end{array}$ \\
\hline$G W-221-U^{*}$ & 8 & -0.757 & 0.456 & -1.474 & 0.994 & -121 & -2.47 \\
\hline$G W-222-F$ & 1 & 0.178 & & 0.021 & & & \\
\hline GW-222-U & 1 & 0.182 & & 0.095 & & & \\
\hline GW-223-F & 7 & -0.539 & 0.471 & -1.619 & 0.305 & -1.01 & -1.92 \\
\hline GW-223-U & 8 & -7.051 & 0.470 & -14.705 & 0.340 & -7.52 & -15.05 \\
\hline GW-225-U & 1 & -1.347 & & -3.178 & & & \\
\hline GW-226-F & 10 & -1.070 & 1.147 & -2.610 & 1855 & -2.22 & -4.47 \\
\hline$G W-226-U$ & 11 & -1.072 & 1.134 & -2.575 & 1864 & -2.21 & -4.44 \\
\hline GW-227-F & 2 & 0.002 & 0.128 & -0.508 & -0.253 & -0.13 & -0.26 \\
\hline GW-227-U & 3 & 0.003 & 0.129 & -0.570 & -0.269 & -0.13 & -0.30 \\
\hline GW-228-F & 5 & -0.059 & 0.608 & -0.150 & 0.969 & -0.67 & -1.12 \\
\hline GW-228-U & 2 & 0.372 & 0.387 & 0.400 & 0.538 & -0.02 & -0.07 \\
\hline GW-229-F & 8 & -0.451 & 0.570 & -1.391 & 0.541 & -1.02 & -1.96 \\
\hline GW-229-U & 8 & -0.450 & 0.569 & -1.404 & 0.539 & -1.02 & -1.94 \\
\hline GW-240-F & 9 & -1.009 & 0.142 & -2.196 & 0.132 & -1.15 & -233 \\
\hline GW-240-U & 8 & -1.028 & 0.138 & -2.166 & 0.108 & -1.17 & -2.27 \\
\hline $\mathrm{GW}-241 \ldots \mathrm{F}^{*}$ & 10 & -0.928 & 0.823 & -1.820 & 1.700 & -1.75 & -3.53 \\
\hline GW-241-U & 6 & -0.941 & 0.195 & -1.841 & 0.397 & -1.14 & -2.24 \\
\hline GW-278-F & 3 & -0.772 & 0.773 & -2.300 & 0.783 & -1.55 & -3.08 \\
\hline GW-278-U & 3 & -0.771 & 0.773 & -2300 & 0.790 & -1.54 & 3.09 \\
\hline GW-279-F & 1 & 1.277 & & 2.503 & & & \\
\hline$G W-293 \ldots F$ & 10 & -0.680 & 0.373 & .1 .250 & 0.817 & -1.05 & -2.07 \\
\hline GW-293-U & 9 & -0.673 & 0.374 & .1 .231 & 0.813 & -1.05 & -2.04 \\
\hline GW-298-F & 8 & -0.717 & 0.366 & -1349 & 0803 & -1.08 & -2.21 \\
\hline GW-298-U & 3 & 0.050 & 0.192 & 0.115 & 0.413 & -0.14 & -0.30 \\
\hline GW-299-F & 10 & -0.865 & 0.064 & -1.62 & 0.158 & -0.93 & -1.85 \\
\hline GW-299-U & 10 & -0.865 & 0.064 & -1.603 & 0.158 & -0.98 & -1.85 \\
\hline GW-300-F & 9 & -1.075 & 0.532 & -2.141 & 1.117 & -1.61 & 3.26 \\
\hline GW-300-U & 9 & -1.056 & 0.521 & -2.123 & 1.084 & -1.58 & -3.21 \\
\hline GW-30G-F & 4 & -0.345 & 0.021 & -1.328 & -0.628 & -0.37 & -0.70 \\
\hline GW-306-U & 2 & -0.053 & 0.021 & -0.656 & -0.628 & -0.08 & -0.03 \\
\hline GW-309-F & 3 & -0.149 & -0.111 & -0.981 & -0.892 & -0.04 & -0.09 \\
\hline GW-309-U & 3 & -0.149 & -0.110 & -0.980 & -0.908 & -0.04 & -0.07 \\
\hline$G W-313-F$ & 2 & -0.023 & 0.290 & -0.522 & 0.118 & -0.31 & -0.64 \\
\hline GW-313-U & 3 & -0.591 & 0290 & -1.675 & 0.118 & -0.88 & -1.79 \\
\hline GW-314-F & 1 & -0.080 & & -0.495 & & & \\
\hline GW-314-U & 1 & -0.072 & & -0.468 & & & \\
\hline GW-315-F & 1 & 0.438 & & 0.405 & & & \\
\hline GW-315-U & 1 & 0.438 & & 0.405 & & & \\
\hline GW-316-F & 3 & -0.574 & -0.517 & -1.222 & -1.138 & -0.06 & -0.08 \\
\hline GW-316-U & 4 & -0.583 & 0.532 & -1.230 & 0.857 & -1.12 & -2.09 \\
\hline GW-317-F & 6 & -0.502 & 0.576 & -0.930 & 1.041 & -1.08 & -1.97 \\
\hline GW-317-U & 5 & 0.124 & 0.583 & 0.158 & 1003 & -0.46 & -0.87 \\
\hline GW-322-F & 10 & -1.016 & 0.395 & -1.990 & 0.828 & -1.41 & -2.82 \\
\hline GW-322-U & 7 & -1.002 & 0398 & -1.976 & 0.848 & -1.40 & -2.82 \\
\hline GW-323-F & 4 & -0.870 & 0.359 & -1.679 & 0.770 & -1.23 & -245 \\
\hline$G W \cdot 323-U$ & 4 & -0.860 & 0.544 & .1 .660 & 0.538 & -1.40 & -2.21 \\
\hline$G W \cdot 350-F$ & 3 & -0.772 & -0.520 & -2.411 & -1.884 & -0.25 & -0.53 \\
\hline GW-350-U & 3 & -0.777 & -0.520 & -2.415 & .1 .884 & -0.26 & -0.53 \\
\hline GW-365-F & 4 & -0.411 & 0.041 & -1.260 & -0.402 & -0.45 & -0.86 \\
\hline GW-365-U & 4 & -0.432 & 0.041 & -1.278 & -0.402 & -0.47 & -0.88 \\
\hline GW-511-F & 4 & 0.805 & 1.379 & 1.610 & 2.779 & -0.57 & -1.17 \\
\hline GW-511-U & 3 & 0.807 & 1.023 & 1.575 & 2.051 & -0.22 & -0.48 \\
\hline GW-513-F" & 6 & -0.280 & 1.024 & -0.501 & 2.104 & -1.30 & -2.61 \\
\hline GW-513-U* & 7 & -0.381 & 1.012 & -0.501 & 2073 & -1.39 & -2.57 \\
\hline$G W-521-F$ & 1 & -0.300 & & -0.524 & & & \\
\hline GW-521-U & 1 & -0.300 & & -0.524 & & & \\
\hline
\end{tabular}




\begin{tabular}{|c|c|c|c|c|c|c|c|}
\hline & \# Values & $\begin{array}{l}\text { SI(cal) } \\
\text { Min. }\end{array}$ & $\begin{array}{l}\text { Si(cal) } \\
\text { Max. }\end{array}$ & $\begin{array}{l}\text { SI(dol) } \\
\text { Min. }\end{array}$ & $\begin{array}{l}\text { SI(d) } \\
\text { Max. }\end{array}$ & $\begin{array}{c}\text { Si(cal) } \\
\text { Min-Max }\end{array}$ & $\begin{array}{l}\text { Sl(dol) } \\
\text { Min-Max }\end{array}$ \\
\hline GW-603-F* & 2 & -1.406 & 0.020 & -3.342 & -0.230 & -1.43 & -3.11 \\
\hline GW-603-U & 4 & -0.337 & 0.739 & -0.928 & 1207 & -1.08 & -2.14 \\
\hline GW-604-F* & 4 & -1.780 & -0.450 & -4.010 & -1.110 & -1.33 & -2.90 \\
\hline GW-604-U & 4 & -0.689 & 0.406 & -1553 & 0.029 & -1.10 & -2.19 \\
\hline$G W-621-F$ & 3 & -0.530 & 0.520 & -1580 & 0.520 & -1.05 & -2.11 \\
\hline GW-621--U & 2 & -0.542 & 0.512 & -1564 & 0.511 & -1.05 & -2.08 \\
\hline GW-683-F & 4 & -1.510 & 0.680 & 3360 & 10020 & -2.19 & -4.38 \\
\hline GW-683-U & 3 & -1.571 & -0.270 & 3.421 & -0.740 & -1.30 & -2.68 \\
\hline GW-684-F' & 3 & -1.530 & 0.480 & 3.450 & 0810 & -2.01 & -4.26 \\
\hline GW-684-U* & 3 & -1.535 & 0.480 & 3.451 & 0.800 & -2.02 & -4.25 \\
\hline GW-685-F & 4 & -0.280 & 0.060 & -0.860 & -0.130 & -0.34 & -0.73 \\
\hline GW-685-U & 4 & -0.287 & 0.080 & -0.887 & -0.120 & -0.37 & -0.77 \\
\hline GW-694-F & 3 & -0.300 & -0.250 & -1.010 & -0.970 & -0.05 & -0.04 \\
\hline GW-694-U & 2 & -0.300 & -0.294 & -1.020 & -0.989 & -0.01 & -0.03 \\
\hline GW-695-F' & 4 & 0.070 & 0.910 & 0.220 & 1.920 & -0.84 & -1.70 \\
\hline GW-695-U* & 3 & 0.490 & 1.127 & 1.000 & 2.067 & -0.64 & -1.07 \\
\hline GW-703-F & 4 & -0.660 & 0.400 & -1.160 & 0.750 & -1.06 & -1.91 \\
\hline GW-703-U & 3 & -0.660 & 0.404 & -1.180 & 0.746 & -1.06 & -1.90 \\
\hline GW-704-F & 4 & 0.148 & 0.470 & 0.175 & 0.890 & -0.32 & -0.72 \\
\hline GW-704-U & 4 & 0.140 & 0.473 & 0.168 & 0.878 & -0.33 & -0.71 \\
\hline$G W-706-F$ & 3 & 0.060 & 0.416 & -0280 & 0.610 & -0.36 & -0.89 \\
\hline GW-706-U & 3 & 0.063 & 0.411 & -0.289 & 0.511 & -0.35 & -0.90 \\
\hline GW-710-F & 1 & 0.364 & & 0.543 & & & \\
\hline GW-710-U & 1 & 0.371 & & 0.548 & & & \\
\hline GW-711-F & 3 & -0.110 & 0.619 & -0.310 & 1.113 & -0.73 & -1.42 \\
\hline GW-711-U & 2 & -0.114 & 0.621 & -0.305 & 1.122 & -0.74 & -1.43 \\
\hline GW-712-F & 2 & 0.235 & 0.406 & 0.365 & 0.673 & -0.17 & -0.31 \\
\hline GW-712--U & 2 & 0236 & 0.406 & 0350 & 0.665 & -0.17 & -0.32 \\
\hline GW-722-02-F & 1 & -0.378 & & -0.812 & & & \\
\hline GW-722-06-F & 1 & 0.022 & & 0.029 & & & \\
\hline GW-722-10-F & $t$ & -0.476 & & -0.982 & & & \\
\hline$G W-722-17-F$ & 1 & -0.608 & & -1.131 & & & \\
\hline GW-722-20-F & 1 & 0.303 & & 0.599 & & & \\
\hline GW-722-22-F & 1 & -0.848 & & -1.818 & & & \\
\hline GW-722-26-F & 1 & -0.038 & & -0.137 & & & \\
\hline GW-722-30-F & 1 & -1.101 & & -2.449 & & & \\
\hline GW-722-32-F & 1 & 0.521 & & 0.391 & & & \\
\hline GW-722-33-F & 1 & -0.513 & & -1.727 & & & \\
\hline GW-723-F F & 1 & 0.693 & & 1.590 & & & \\
\hline GW-733-U* & 1 & 0.575 & & 1366 & & & \\
\hline GW-733-F & 1 & 0.553 & & 1347 & & & \\
\hline$G W-734-F$ & 1 & -0.447 & & -1.559 & & & \\
\hline$G W-734-U$ & 2 & -0.783 & -0.435 & -1.900 & -1.419 & -0.35 & -0.48 \\
\hline$G W-735-U$ & 1 & -0.133 & & -1.159 & & & \\
\hline GW-735-F & 1 & -0.133 & & -1.143 & & & \\
\hline GW-739-F & 1 & -0.123 & & -0.326 & & & \\
\hline GW-739-U & 1 & -0.118 & & -0.307 & & & \\
\hline GW-740--F & 1 & -0.015 & . & -0.099 & & & \\
\hline GW-740-U & 1 & -0.025 & & -0.120 & & & \\
\hline
\end{tabular}

Note: U refers to the unfiltered samples, F refers to the fittered samples.

Wells followed by an " had partial pressures of carbon dioxide near atmospheric values.

Entries in italics indicate consistent undersaturation with respect to calcite.

Entries in bold indicate fluctuations between super- and undersaturation with respect to dolorite occurs between sampling events 
Table 2: Wells With Magnesium to Calcium Ratios Suggestive of Flow from the Ccr

Well

Average Minimum Maximum Consistent Drilled

$a(\mathrm{Mg}) / \mathrm{a}(\mathrm{Ca}) \quad \mathrm{a}(\mathrm{Mg}) / \mathrm{a}(\mathrm{Ca}) \quad \mathrm{a}(\mathrm{Mg}) / \mathrm{a}(\mathrm{Ca}) \quad$ or Fluctuating Through

the $\mathrm{Cor}$

Picket W Area:

GW-710

GW-711

0.61

0.71

GW-712

0.69

0.60

0.65

0.65

0.61

0.76

0.75

Picket A Area:

GW-684

0.51

0.38

0.65

F

$Y$

Picket B Area:

GW-703

1.04

0.86

0.78

0.73

GW-706

0.52

0.35

1.42

1.21

0.86

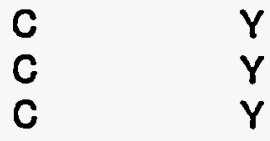

Picket C Area:

GW-228

0.59

0.46

0.95

GW-723

1.47

GW-739

0.77

0.76

0.78

GW-740

0.76

0.76

0.78

0.76

$\begin{array}{ll}\text { C } & \text { Y } \\ \text { C } & \text { N } \\ \text { F } & \text { N }\end{array}$

S-3 Ponds Area:

GW-135-03

0.62

0.83

GW-135-19

0.75

GW-279

0.71

GW-316

0.74

0.56

0.71

-

$-$

-

GW-317

0.61

0.78

0.67

1.06

$\begin{array}{ll}\text { F } & \text { N } \\ \text { C } & \text { Y } \\ \text { C } & \text { Y } \\ \text { C } & \text { Y }\end{array}$

Picket J Area:

$\begin{array}{ll}\text { GW-131-4 } & 0.92 \\ \text { GW-131-8 } & 0.92 \\ \text { GW-131-12 } & 0.93 \\ \text { GW-131-15 } & 0.88 \\ \text { GW-151 } & 0.70 \\ \text { GW-153 } & 0.77 \\ \text { GW-240 } & 0.65 \\ \text { GW-604 } & 0.60 \\ \text { GW-722-02 } & 0.75 \\ \text { GW-722-06 } & 0.98 \\ \text { GW-722-10 } & 1.04 \\ \text { GW-722-17 } & 1.03 \\ \text { GW-722-20 } & 1.06 \\ \text { GW-722-22 } & 0.86 \\ \text { GW-722-26 } & 0.75 \\ \text { GW-722-30 } & 0.68 \\ \text { GW-733 } & 1.58\end{array}$

$\begin{array}{cccc}- & - & ? & Y \\ - & - & ? & Y \\ - & - & ? & Y \\ - & - & ? & \text { Y } \\ 0.65 & 0.71 & C & N \\ 0.71 & 1.00 & C & N \\ 0.52 & 0.80 & F & N \\ 0.55 & 0.64 & F & Y \\ - & -- & ? & N \\ - & -- & ? & N \\ - & - & ? & N \\ - & - & ? & N \\ - & - & ? & N \\ - & - & ? & N \\ - & - & ? & N \\ - & - & ? & N \\ 1.53 & 1.62 & C & Y\end{array}$

Note: A "?" in the fifth column indicates only one analysis is available. 
Table 3. Deuterium (D), oxygen-18 (0-18), and carbon-13 (C-13) in the Maynardville Limestone ( $\mathrm{Cmn}$ ) and Copper Ridge Dolomite (Ca).

\begin{tabular}{|c|c|c|c|c|c|c|c|}
\hline Well & $\begin{array}{l}\text { Depth } \\
\text { (m) }\end{array}$ & Complete & $\mathrm{Fm}$ & Date & $\begin{array}{c}0-18 \\
\text { (per mil) }\end{array}$ & $\begin{array}{c}D \\
\text { (per mil) }\end{array}$ & $\begin{array}{c}\text { C-13 } \\
\text { (per mil) }\end{array}$ \\
\hline GW-131-12 & 237.7 & $F$ & $\mathrm{Car}$ & $5 / 19 / 92$ & -6.93 & -32.6 & -9.53 \\
\hline GW-131-24 & 139.6 & $F$ & $\mathrm{Ccr}$ & $5 / 19 / 92$ & -7.13 & -35.1 & -- \\
\hline GW-131-28 & 114.6 & $\mathbf{N}$ & Cor & $5 / 19 / 92$ & -7.07 & -34.2 & -9.02 \\
\hline$G W-134-11$ & 176.2 & $F$ & $\mathrm{Cn}$ & $6 / 25 / 92$ & -7.44 & -29.6 & -6.75 \\
\hline GW-134-15 & 148.1 & $F$ & $\mathrm{Cn}$ & $6 / 23 / 92$ & - & - & -11.78 \\
\hline GW-134-18 & 129.8 & $F$ & $\mathrm{Cn}$ & 4/13/92 & -7.35 & -28 & - \\
\hline GW-134-25 & 87.2 & $F$ & $\mathrm{Cn}$ & $5 / 5 / 92$ & -7 & -34.6 & -3.59 \\
\hline GW-134-29 & 52.1 & $\mathbf{F}$ & $\mathrm{Cn}$ & $5 / 11 / 92$ & -6.54 & -29.9 & - \\
\hline GW-134-3 & 239.3 & $F$ & Cn & $5 / 4 / 92$ & -7.29 & -25.2 & -. \\
\hline GW-134-33 & 32.3 & $F$ & $\mathrm{Cn}$ & $5 / 11 / 92$ & -6.8 & -34.3 & .. \\
\hline GW-135-03 & 367.6 & $\mathbf{N}$ & $\mathrm{Cmn}$ & $2 / 13 / 92$ & -7.24 & -28.6 & $-14.17^{*}$ \\
\hline GW-135-03 & 367.6 & $\mathbf{N}$ & $\mathrm{Cmn}$ & 6/2/92 & -6.88 & -25.7 & -- \\
\hline GW-135-11 & 294.1 & $F$ & Cmn & $6 / 8 / 92$ & -7.72 & -34.2 & $-10.65^{*}$ \\
\hline GW-135-30 & 139.9 & $F$ & $\mathrm{Car}$ & $6 / 9 / 92$ & -7.46 & -35.4 & -10.8 \\
\hline GW-135-41 & 50.0 & $F$ & $\mathrm{Ccr}$ & $2 / 13 / 92$ & -7.46 & -34.6 & -12.83 \\
\hline GW-722-02 & 189.0 & $\mathbf{N}$ & $\mathrm{Cmn}$ & $5 / 27 / 92$ & -7.61 & -34.6 & -5.66 \\
\hline GW-722-06 & 170.7 & $\mathbf{N}$ & $\mathrm{Cmn}$ & $1 / 792$ & -7.46 & -38.1 & -7.22 \\
\hline GW'-722-10 & 152.4 & $F$ & Cmn & $1 / 20 / 92$ & -7.12 & -36 & - \\
\hline GW-722-17 & 117.3 & $\mathbf{F}$ & Cmn & $5 / 28 / 92$ & -6.96 & -30.4 & -8.22 \\
\hline GW-722-20 & 101.5 & $F$ & $\mathrm{Cmn}$ & $1 / 21 / 92$ & -6.81 & -35 & -6.15 \\
\hline GW-722-22 & 95.4 & $\mathbf{F}$ & $\mathrm{Cmn}$ & $1 / 27 / 92$ & -7 & -35 & - \\
\hline GW-722-26 & 65.8 & $\mathbf{N}$ & $\mathrm{Cmn}$ & $5 / 21 / 92$ & -7.39 & -33.8 & -- \\
\hline GW-722-30 & 46.0 & $\mathbf{F}$ & $\mathrm{Cmn}$ & $1 / 29 / 92$ & -7.27 & -36.1 & -10.01 \\
\hline GW-722-32 & 32.6 & C & Cmn & $1 / 29 / 92$ & -7.17 & -38.4 & - \\
\hline GW-722-33 & 26.5 & C & $\mathrm{Cmn}$ & 2/4/92 & -7.19 & -40.7 & -8.77 \\
\hline \multirow[t]{7}{*}{ GW-734 } & 19.8 & C & Cmn & $3 / 24 / 92$ & -7.46 & -33.1 & - \\
\hline & & & & Average (all): & -7.19 & -33.33 & -8.49 \\
\hline & & & & Std. Deviation & 0.28 & 3.8 & 2.60 \\
\hline & & & & Average (Cmn) & -7.23 & -34.26 & -7.67 \\
\hline & & & & Std. Deviation & 0.27 & 3.95 & 1.65 \\
\hline & & & & Average (Ccr) & -7.21 & -34.38 & -10.55 \\
\hline & & & & Std. Deviation & 0.24 & 1.10 & 1.70 \\
\hline
\end{tabular}

Note: "Low yield

GW-134 is completed in the Nolichucky Shale (Cn).

$\mathrm{Fm}=$ geologic formation.

Completed in fracture $(F)$, cavity $(C)$, or neither $(N)$ 
Table 4. Percentage of total data points by season having deuterium enriched ( $>1$ per mil) or depleted (>-1 per mil) relative to the WMWL

\begin{tabular}{|c|c|c|c|c|c|c|}
\hline & $\begin{array}{l}\text { Hatteras, } \\
\text { NC }\end{array}$ & $\begin{array}{c}\text { Waco, } \\
\text { TX }\end{array}$ & $\begin{array}{l}\text { San Juan, } \\
\text { Puerto Rico }\end{array}$ & $\begin{array}{l}\text { Veracruz, } \\
\text { Mexico }\end{array}$ & Average* & Averaget \\
\hline \multicolumn{7}{|c|}{ Above WMWL (>1 per mil) } \\
\hline April to Sept. & $28.6 \%$ & $33.0 \%$ & $12.5 \%$ & $45.0 \%$ & $24.7 \%$ & $29.8 \%$ \\
\hline Oct. to March & $71.4 \%$ & $66.0 \%$ & $87.5 \%$ & $55.0 \%$ & $75.0 \%$ & $70.0 \%$ \\
\hline Number of Values & 49 & 42 & 8 & 51 & & \\
\hline \multicolumn{7}{|c|}{ Below WMWL (>-1 per mil) } \\
\hline April to Sept. & $81.0 \%$ & $71.4 \%$ & $85.7 \%$ & $61.0 \%$ & $79.4 \%$ & $74.8 \%$ \\
\hline Oct. to March & $18.5 \%$ & $28.6 \%$ & $14.3 \%$ & $39.0 \%$ & $20.5 \%$ & $25.1 \%$ \\
\hline Number of Values & 27 & 42 & 7 & 56 & & \\
\hline
\end{tabular}

Average* is average of Hatteras, Waco, San Juan

Average+ is average of Hatteras, Waco, San Juan, Veracnuz 
Table 5. Measured and modeled carbon-13 (per mil PDB) under open and closed system dissolution conditions.

Assume: Closed System C-13 Carbonate a -1.0 per mil. Closed System C-13 Cakcite and Dolomite $=-1.0$ per mil

\begin{tabular}{|c|c|c|c|c|c|c|c|c|c|c|c|c|}
\hline \multirow[b]{2}{*}{ Zone } & \multirow[b]{2}{*}{ Date } & \multirow[b]{2}{*}{$\begin{array}{c}\text { Measured } \\
\text { C-13 } \\
\end{array}$} & \multicolumn{3}{|c|}{$\begin{array}{c}\text { Inilial } \mathrm{C}-13 \mathrm{CO} 2=-25 \text { per mil } \\
\text { Recharge } \mathrm{T}=25 \mathrm{C}\end{array}$} & \multicolumn{3}{|c|}{$\begin{array}{c}\text { Initial C-13 CO2 }=-13 \text { per mil } \\
\text { Recharge } T=5 \mathrm{C}\end{array}$} & \multicolumn{3}{|c|}{ 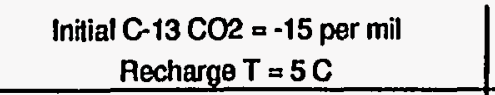 } & \multirow[b]{2}{*}{$\begin{array}{l}\text { Percent } \\
\text { Error }\end{array}$} \\
\hline & & & $\begin{array}{c}\text { Open } \\
\text { System }\end{array}$ & $\begin{array}{l}\text { Closed } \\
\mathrm{CaCO3}\end{array}$ & $\begin{array}{l}\text { Closed } \\
\text { CavDol }\end{array}$ & $\begin{array}{c}\text { Open } \\
\text { System }\end{array}$ & $\begin{array}{l}\text { Closed } \\
\text { CaCO3 }\end{array}$ & $\begin{array}{l}\text { Closed } \\
\text { CavDol }\end{array}$ & $\begin{array}{c}\text { Open } \\
\text { System }\end{array}$ & $\begin{array}{l}\text { Closed } \\
\mathrm{CaCO} 3\end{array}$ & $\begin{array}{l}\text { Closed } \\
\text { CalDol }\end{array}$ & \\
\hline$G W \cdot 131-12$ & $5 / 19 / 92$ & -9.53 & -17.08 & -13.40 & -15.96 & -2.80 & -6.56 & $-9.38^{*}$ & -4.8 & -7.66 & -9.73 & $1.6 \%$ \\
\hline$G W-131-28$ & $5 / 19 / 92$ & -9.02 & & -13.23 & 18.68 & & -6.71 & $-9.48^{*}$ & & -7.77 & 10.48 & $4.9 \%$ \\
\hline GW-135-03 & $2 / 13 / 92$ & -14.17 & & -16.43 & 169.20 & & -3.48 & 84.10 & & -5.32 & 98.28 & \\
\hline$G W-135-11$ & 8/8/92 & -10.65 & & -13.27 & 4.76 & & -6.69 & -12.92 & & -7.75 & 2.36 & $17.6 \%$ \\
\hline$G W-135-20$ & $6 / 9 / 92$ & -10.8 & & -13.80 & -15.23 & & -8.16 & -8.11 & & -7.36 & -9.30 & $14.0 \%$ \\
\hline GW-135-41 & $2 / 13 / 92$ & -12.83 & & -12.93 & -9.42 & & -6.85 & -5.21 & & -7.86 & -5.91 & $0.8 \%$ \\
\hline GW-722-02 & $5 / 27 / 92$ & -5.66 & & -12.99 & -24.46 & & -6.85 & -12.73 & & -7.86 & -14.69 & $17.4 \%$ \\
\hline GW-722-06 & $1 / 7 / 92$ & -7.22 & & -12.96 & -20.51 & & -6.85 & -10.76 & & -7.86 & -12.38 & $5.4 \%$ \\
\hline GW-722-17 & $5 / 28 / 92$ & -8.22 & & -14.07 & -15.06 & & -5.89 & -8.03 & & -7.16 & -9.20 & $2.4 \%$ \\
\hline GW-722-20 & $1 / 21 / 92$ & -6.15 & & -13.11 & -13.65 & & -6.80 & -7.33 & & -7.84 & -8.38 & $9.6 \%$ \\
\hline GW-722-30 & 1/29/92 & -10.01 & & -14.47 & -17.18 & & -5.48 & -9.09 & & -6.84 & -10.44 & $4.1 \%$ \\
\hline GW-722-33 & 2/4/92 & -8.77 & & -13.94 & $-15.72 \mid$ & & -6.03 & -8.36 & & -7.26 & -9.58 & $4.9 \%$ \\
\hline
\end{tabular}

Assume: Closed System C-13 Carbonate $(\mathrm{Cmn})=0.13$ per mil. Closed System C-13 Calcite $=-1.97$ per mil, and Dolomite $=-0.84$ per mil

\begin{tabular}{|c|c|c|c|c|c|c|c|c|c|c|c|c|}
\hline \multirow[b]{2}{*}{ Zone } & \multirow[b]{2}{*}{ Date } & \multirow[b]{2}{*}{$\begin{array}{c}\text { Measured } \\
\text { C-13 } \\
\end{array}$} & \multicolumn{3}{|c|}{$\begin{aligned} \text { Initial } \mathrm{C}_{13} \mathrm{CO} 2 & =-25 \text { per mil } \\
\text { Recharge } T & =25 \mathrm{C}\end{aligned}$} & \multicolumn{3}{|c|}{$\begin{array}{c}\text { Initial } \mathrm{C}-13 \mathrm{CO} 2=-13 \text { per mil } \\
\text { Recharge } T=5 \mathrm{C}\end{array}$} & \multicolumn{3}{|c|}{$\begin{array}{c}\text { Initial } \mathrm{C}-13 \mathrm{CO} 2=-15 \text { per mil } \\
\text { Recharge } \mathrm{T}=5 \mathrm{C}\end{array}$} & \multirow[b]{2}{*}{$\begin{array}{l}\text { Percent } \\
\text { Error }\end{array}$} \\
\hline & & & $\begin{array}{c}\text { Open } \\
\text { System }\end{array}$ & $\begin{array}{l}\text { Closed } \\
\text { Caco3 } \\
\end{array}$ & $\begin{array}{l}\text { Closed } \\
\text { CallDol }\end{array}$ & $\begin{array}{c}\text { Open } \\
\text { System }\end{array}$ & $\begin{array}{l}\text { Closed } \\
\mathrm{CaCO} 3\end{array}$ & $\begin{array}{l}\text { Closed } \\
\text { CallDol }\end{array}$ & $\begin{array}{l}\text { Open } \\
\text { System }\end{array}$ & $\begin{array}{l}\text { Closed } \\
\mathrm{CaCO} 3 \\
\end{array}$ & $\begin{array}{l}\text { Closed } \\
\text { Callool }\end{array}$ & \\
\hline GW-131-12 & $5 / 19 / 92$ & -9.63 & -17.08 & -12.90 & -15.92 & -2.80 & -6.05 & -8.44 & -4.8 & -7.16 & -9.68 & $1.5 \%$ \\
\hline GW-131-28 & $5 / 19 / 92$ & -9.02 & & -12.70 & 18.71 & & -6.19 & 8.87 & & -7.25 & $-9.39^{*}$ & $3.9 \%$ \\
\hline GW-135-03 & $2 / 13 / 92$ & -14.17 & & -16.34 & 168.41 & & -3.39 & 83.31 & & -5.23 & 97.49 & \\
\hline$G W-135-11$ & $6 / 8 / 92$ & -10.65 & & -12.68 & 4.37 & & -6.16 & $-12.12^{4}$ & & -7.23 & 1.97 & $12.1 \%$ \\
\hline$G W-135-30$ & 6/9/92 & -10.8 & & -13.35 & -15.16 & & -5.71 & -8.04 & & -6.91 & $-9.37^{*}$ & $13.2 \%$ \\
\hline$G W-135-41$ & $2 / 13 / 92$ & -12.83 & & -12.38 & -9.43 & & -6.31 & -5.23 & & -7.31 & -5.99 & $3.6 \%$ \\
\hline GW-722-02 & $5 / 27 / 92$ & -5.66 & & -12.44 & -24.46 & & -6.30 & -12.73 & & -7.32 & -14.69 & $11.3 \%$ \\
\hline GW-722-08 & $1 / 7 / 92$ & -7.22 & & -12.42 & -20.48 & & -6.31 & -10.73 & & -7.32 & -12.35 & $1.4 \%$ \\
\hline GW-722-17 & $5 / 28 / 92$ & -8.22 & & -13.68 & -14.98 & & -5.48 & -8.42 & & -6.74 & -9.12 & $2.4 \%$ \\
\hline GW-722-20 & $1 / 21 / 92$ & -6.15 & & -12.57 & -13.55 & & -6.26 & -7.23 & & -7.30 & -8.28 & $1.8 \%$ \\
\hline GW-722-30 & $1 / 29 / 92$ & -10.01 & & -14.11 & -17.29 & & -5.12 & -9.11 & & -6.49 & -10.46 & $4.5 \%$ \\
\hline GW-722-33 & $2 / 4 / 92$ & -8.77 & & -13.51 & -15.91 & & -5.60 & -8.55 & & -6.83 & -9.78 & $2.6 \%$ \\
\hline
\end{tabular}

Nole: Calculaled values in bold are the most similar to the measured value in the row.

\footnotetext{
- Includes dissolution of gypsum.
} 
Table 6. Wells which may reflect a quickflow environment as suggested by geochemical indicator parameters.

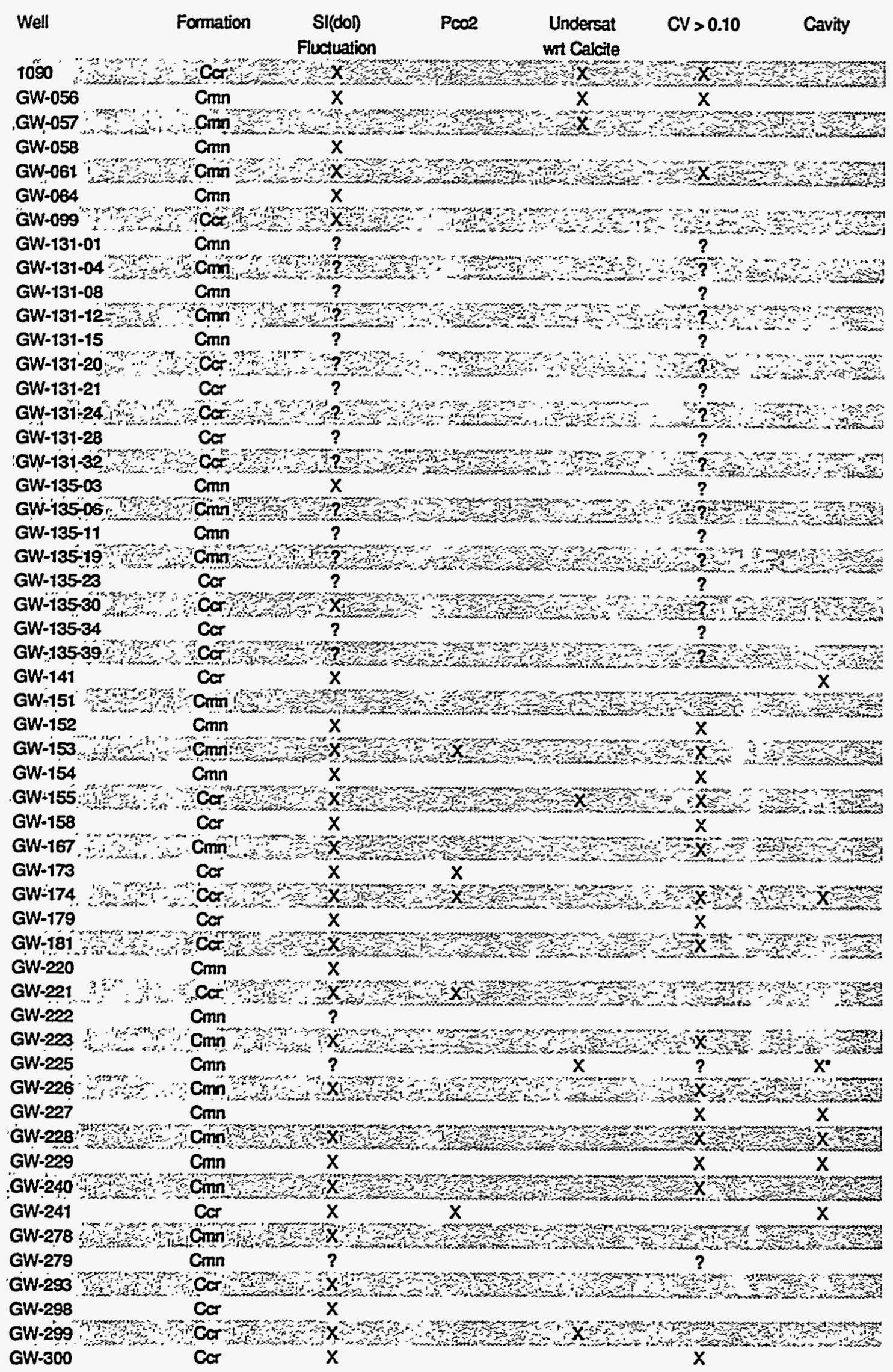




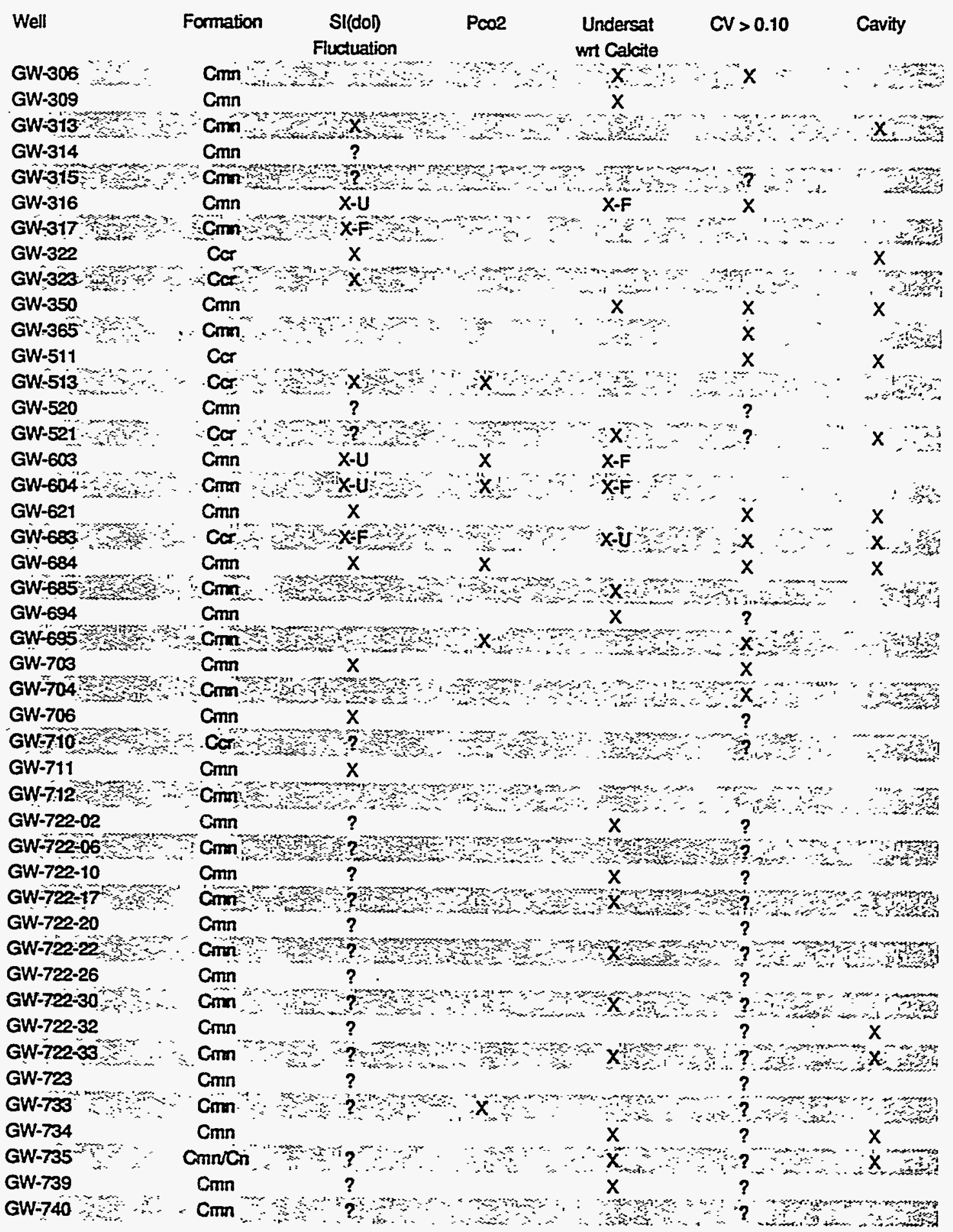

$A " ? "$ in the above columns indicates that insulficient temporal data are available for the particular well. A blank in a column indicates data are available for the parameter, yet no indications of quick flow can be inferred $X-U$ - indicates the " $X$ " is true for the unfittered samples only.

$X-F$ - indicates the " $X$ " is true for the fittered samples only. 
Appendix A: Calculated hardnesses, coefficients of variation of hardness, and flow through times for waters in the Maynardville Limestone and Copper Ridge Dolomite.

$F$ refers to the filtered sample. $U$ refers to the unfittered sample.

\begin{tabular}{|c|c|c|c|c|c|c|c|c|c|c|c|}
\hline Well & $\begin{array}{c}\mathrm{Ca} \\
\text { Average } \\
(\mathrm{mg} / \mathrm{L})\end{array}$ & $\begin{array}{c}\mathrm{Ca} \\
\text { Stder } \\
\text { (mg/L) }\end{array}$ & $\begin{array}{c}\mathrm{Mg} \\
\text { Average } \\
\text { (mg/l) }\end{array}$ & $\begin{array}{c}\mathrm{Mg} \\
\text { Stdev } \\
(\mathrm{mg} / \mathrm{L})\end{array}$ & $\begin{array}{c}\text { Hardness } \\
\text { Average } \\
\text { (mg/L) }\end{array}$ & $\begin{array}{l}\text { Hardness } \\
\text { Stdev } \\
\text { (mg/h) }\end{array}$ & $\mathrm{CV}$ & $\begin{array}{c}\text { \# of } \\
\text { Values }\end{array}$ & $\begin{array}{l}\text { Flow Thru } \\
\text { time (d) }\end{array}$ & $\begin{array}{l}\mathrm{Q}(\mathrm{m} 3 / \mathrm{s}) \\
\text { Average }\end{array}$ & $\begin{array}{c}Q(\mathrm{~m} 3 / \mathrm{s}) \\
\text { Stdev }\end{array}$ \\
\hline $1090--F$ & 50.8 & 4.4 & 29.7 & 1.6 & 248.8 & 16.6 & 0.07 & 10 & 23.62 & 0.69 & 0.26 \\
\hline $1090 .-U$ & 57.2 & 17.3 & 35.9 & 13.3 & 290.2 & 97.5 & 0.34 & 10 & 1.08 & 0.6 & 0.4 \\
\hline GW-056--F & 67.3 & 7.1 & 22.5 & 1.9 & 260.4 & 25.5 & 0.10 & 4 & 11.33 & 0.6 & 0.3 \\
\hline GW-056-U & 81.4 & 5.6 & 26.6 & 1.7 & 312.6 & 20.2 & 0.06 & 5 & 25.08 & 0.2 & 0.1 \\
\hline GW-057--F & 84.5 & 2.1 & 17.0 & 0.0 & 281.0 & 5.3 & 0.02 & 2 & 263.11 & 0.3 & 0.0 \\
\hline GW-057--U & 83.0 & 2.8 & 16.5 & 0.7 & 275.2 & 4.2 & 0.02 & 2 & 399.69 & 0.4 & 0.0 \\
\hline GW-058--F & 75.3 & 1.5 & 27.8 & 2.2 & 301.9 & 10.6 & 0.04 & 4 & 80.68 & 0.2 & 0.0 \\
\hline GW-058--U & 75.3 & 3.1 & 28.0 & 2.7 & 302.9 & 16.7 & 0.06 & 4 & 34.03 & 0.2 & 0.1 \\
\hline$G W \cdot 061-\ldots F$ & 79.0 & 21.0 & 11.1 & 4.0 & 242.8 & 68.8 & 0.28 & 4 & 1.50 & 1.1 & 0.8 \\
\hline GW-061--U & 84.0 & 22.6 & 11.4 & 4.0 & 256.9 & 72.7 & 0.28 & 3 & 1.50 & 0.9 & 0.7 \\
\hline GW-064-o-F & 106.7 & 5.8 & 16.0 & 0.0 & 332.3 & 14.4 & 0.04 & 3 & 53.62 & 0.1 & 0.0 \\
\hline GW-064--U & 110.0 & 0.0 & 16.0 & 0.0 & 340.6 & 0.0 & 0.00 & 3 & & 0.1 & 0.0 \\
\hline GW-095--F & 1.3 & 0.1 & 0.4 & 0.0 & 4.7 & 0.4 & 0.08 & 6 & 18.16 & 92.9 & 0.7 \\
\hline GW-095--U & 1.4 & 0.1 & 0.4 & 0.0 & 5.1 & 0.4 & 0.08 & 6 & 16.99 & 92.2 & 0.8 \\
\hline GW-099--F & 26.0 & 1.4 & 15.5 & 0.7 & 128.6 & 6.4 & 0.05 & 2 & 40.91 & 7.5 & 1.0 \\
\hline GW-099--U & 26.5 & 0.7 & 15.5 & 0.7 & 129.8 & 1.1 & 0.01 & 2 & 1149.66 & 7.3 & 0.2 \\
\hline$G W-131-1-. F$ & 65 & & 34 & & 302 & & & 1 & & 0.22 & \\
\hline GW-131-12--F & 49 & & 28 & & 237 & & & 1 & & 0.82 & \\
\hline GW-131-15-F & 62 & & 34 & & 294 & & & 1 & & 0.26 & \\
\hline$G W-131-20-F$ & 240 & & 140 & & 1174 & & & 1 & & 0.00 & \\
\hline$G W-131-21-F$ & 240 & & 120 & & 1092 & & & 1 & & 0.00 & \\
\hline GW-131-24-F & 350 & & 210 & & 1736 & & & 1 & & 0.00 & \\
\hline GW-131-32-F & 34 & & 19 & & 163 & & & 1 & & 3.72 & \\
\hline GW-131-4--F & 61 & & 35 & & 296 & & & 1 & & 0.25 & \\
\hline$G W-131-8--F$ & 35 & & 20 & & 170 & & & 1 & & 3.25 & \\
\hline GW-132-1--F & 0.5 & & 0.092 & & 2 & & & 1 & & 98.95 & \\
\hline GW-132-17-F & 0.65 & & 0.072 & & 2 & & & 1 & & 98.36 & \\
\hline$G W-132-21-F$ & 1.4 & 0.3 & 0.2 & 0.1 & 4.1 & 1.1 & 0.26 & 3 & 1.75 & 94.0 & 2.1 \\
\hline GW-132-25--F & 5.0 & 2.1 & 1.3 & 0.5 & 17.6 & 7.0 & 0.40 & 2 & 0.78 & 71.9 & 10.2 \\
\hline GW-132-5--F & 0.82 & 0 & 0.11 & 0 & 3 & 0 & & 1 & & 97.21 & 0 \\
\hline GW-132-9--F & 0.51 & 0 & 0.057 & 0 & 2 & 0 & & 1 & & 99.19 & 0 \\
\hline GW-133-1-F & 1.6 & 0 & 0.48 & 0 & 6 & 0 & & 1 & & 90.59 & 0 \\
\hline GW-133-10- & 0.89 & 0 & 0.2 & 0 & 3 & 0 & & 1 & & 96.14 & 0 \\
\hline GW-133-17-- & 1.6 & 0 & 0.41 & 0 & 6 & $\dot{0}$ & & 1 & & 91.12 & 0 \\
\hline GW-133-24--f & 21 & 0 & 5.5 & 0 & 75 & 0 & & 1 & & 22.22 & 0 \\
\hline$G W-133-5-. F$ & 1.3 & 0 & 0.3 & 0 & 4 & 0 & & 1 & & 93.37 & 0 \\
\hline$G W-134-11-F$ & 15 & 0 & 3.9 & 0 & 53 & 0 & & 1 & & 34.46 & 0 \\
\hline$G W-134-18-F$ & 57.5 & .7 .8 & 13.5 & 0.7 & 199.1 & 22.3 & 0.11 & 2 & 8.76 & 1.9 & 0.8 \\
\hline GW-134-25--F & 2.8 & 1.6 & 0.7 & 0.4 & 9.7 & 5.6 & 0.58 & 2 & 0.39 & 84.3 & 9.5 \\
\hline GW-134-29-.F & 1.4 & 0 & 0.3 & 0 & 5 & 0 & & 1 & & 92.90 & 0 \\
\hline GW-134-3--F & 130 & 0 & 38 & 0 & 481 & 0 & & 1 & & 0.01 & 0 \\
\hline GW-134-33--F & 280 & 0 & 56 & 0 & 930 & 0 & & 1 & & 0.00 & 0 \\
\hline GW-134-5-F & 110 & 0 & 32 & 0 & 406 & $=0$ & & 1 & & 0.03 & 0 \\
\hline GW-135-11-F & 200 & 0 & 58 & 0 & 738 & 0 & & 1 & & 0.00 & 0 \\
\hline GW-135-19-F & 39 & 0 & 20 & 0 & 180 & 0 & & 1 & & 2.66 & 0 \\
\hline GW-135-23--F & 540 & 0 & 130 & 0 & 1883 & 0 & & 1 & & 0.00 & 0 \\
\hline GW-135-3--F & 1620.0 & 216.8 & 586.0 & 132.4 & 6452.6 & 1079.1 & 0.17 & 5 & 4.09 & 0.0 & 0.0 \\
\hline
\end{tabular}


Well

$$
\text { Went }
$$

GW-135-30-F

GW-135-34-F

GW-135-39--F

GW-135-6-F

GW-141--F

GW-141-U

GW-151--F

GW-151--U

GW-152--F

GW-153--F

GW-153--U

GW.154-F

GW.154--U

GW-155-F

GW-155-U

GW-158--F

GW-158-U

GW-167-..F

GW-167-aU

GW-173-F

GW-173-U

GW-174-F

GW-174-U

GW-179-F

GW-179-U

GW-181--F

GW-181-U

GW-220--F

GW-220-U

GW-221-F

GW-221-U

GW-222-F

GW-222--U

GW-223-F

GW-223--U

GW-225-F

GW-225-U

GW-226-F

GW-226--U

GW-227-F

GW-227--U

GW-228--F

GW-228-U

GW-229-F

GW-229-U

GW-240-F

GW-240--U

GW-241-F

GW-241--U

GW-278-F

GW-278-U
Ca

Average

(mg/L)

33.5
32

28

340

38.6

38.9

57.8

56.8

53.7

35.1

38.3

115.0

108.8

28.5

30.8

24.5

23.3

89.5

74.0

39.0

40.4

32.1

37.1

60.2

76.0

30.2

30.1

61.6

65.0

28.5

28.6

38.0

39.0

86.9

90.4

180.0

170.0

163.0

165.8

125.0

130.0

111.2

120.0

166.7

166.7

52.4

50.0

27.7

30.3

62.0

62.7
$\mathrm{Ca} \quad \mathrm{Mg}$

Stder Average

(mg/L) (mg/L)

$$
2.1 \quad 22.0
$$$$
0 \quad 20
$$

$0 \quad 17$

$0 \quad 100$

1.6

1.2

1.9

2.9

12.7

5.9

5.4

7.1

22.5

1.8

4.1

10.1

9.2

29.0

0.0

2.3

5.3

5.9

8.9

3.7

0.0

3.2

3.1

7.9

0.0

1.2

1.4

0.0

0.0

22.9

22.4

0.0

0.0

17.0

19.8

21.2

17.3

38.4

28.3

24.0

24.0

7.9

10.2

2.2

1.3

5.3

4.2

\section{9}

25.2

25.0

24.3

19.1

16.7

17.8

18.5

17.0

17.3

18.8

21.8

21.5

4.7

4.2

24.8

25.0

21.8

24.5

33.7

45.0

18.6

18.6

22.0

23.0

17.9

17.8

9.3

11.0

12.5

12.9

36.0

33.0

33.1

34.9

23.0

23.7

38.6

40.5

28.8

28.7

20.5

20.8

16.7

18.7

5.6

5.7
Mg Hardness Hardness

Stdev Average Stdev

(mg/L) (mg/L) (mg/L)

0.4144 .5

26210.3

$\begin{array}{rrrr}0.0 & 174.0 & 5.3 & 0.03 \\ 0 & 162 & 0 & \\ 0 & 140 & 0 & \end{array}$

0

1.0

1260

1.0

198.6

0.6

200.6

1.0

247.1

4.2

241.3

212.8

$1.9 \quad 156.2$

2.4

168.7

$0.7 \quad 363.4$

$3.6 \quad 341.6$

0.9142 .0

$2.4 \quad 153.9$

0.6

150.7

1.0

146.3

1.1

0.0

242.8

202.2

$1.1 \quad 199.2$

$1.4 \quad 203.6$

3.2169 .5

$4.0 \quad 193.3$

$2.4 \quad 288.5$

0.0

374.5

$1.9 \quad 151.6$

1.8

0.0

151.4

244.2

0.0

256.8

$0.7 \quad 144.3$

$0.0 \quad 133.1$

$0.0 \quad 142.6$

$3.1 \quad 268.3$

$2.7 \quad 278.9$

$0.0 \quad 597.6$

$0.0 \quad 560.3$

2.5

3.1

543.2

557.7

$4.2 \quad 406.8$

4.2

4.9

422.0

436.3

$0.7 \quad 466.1$

$4.4 \quad 534.7$

4.0

534.7

$2.9 \quad 215.1$

1.4

210.3

1.2

137.9

0.6

178.1

$0.5 \quad 180.2$ 
Well

GW-279-1

GW-293-F

GW-293--U

GW-298--F

GW-298-U

GW-299..F

GW-299-U

GW-300--F

GW-300-U

GW-306-..F

GW-306-.U

GW-309-.F

GW-309-LU

GW-313-.F

GW-313--U

GW-314-F

GW-314--U

GW-315-.F

GW-315-U

GW-316-F

GW-316-U

GW-317-F

GW-317-U

GW-322-F

GW-322-U

GW-323--F

GW-323-U

GW-350--F

GW-350--U

GW-365--F

GW-365--U

GW-511--F

GW-511--U

GW-513-.F

GW-513--U

GW-520--F

GW-521--F

GW-521-U

GW-603...F

GW-603 -...U

GW-604-..-F

GW-604-..-U

GW-621-..-F

GW-621-..U

GW-683-...F

GW-683-.-LU

GW-684-...F

GW-684-..-U

GW-685-..F

GW-685-m U
Ca

Average (mg/L)$$
30.0
$$

50.0

89.9

1.2

33.5

37.8

27.6

27.8

27.8

28.0

107.0

112.0

195.0

195.0

110.0

113.3

88.3

90.5

77.0

77.0

58.2

57.6

40.5

42.8

30.0

30.1

40.0

46.3

68.0

67.0

108.0

106.3

15.5

19.7

32.8

33.1

200.0

28.0

28.0

70.2

69.3

43.7

46.5

44.0

44.0

54.3

43.5

40.7

40.3

77.0

76.0
$\mathrm{Ca}$

Stdev Average

(mg/L)
$\mathrm{Mg}$ (mg/L)
Mg Hardness Hardness

Stdev Average Stdev

(mg/L) (mgll) (mg/L)

$$
\begin{array}{llll}
0.0 & 14.0 & 0.0 & 132.4
\end{array}
$$

$0.0 \quad 190.6$

$0.7 \quad 325.2$

3.5

24.5

1.1

1.7

21.6

1.1

0.9

6.6

172.4

$\begin{array}{ll}3.6 & 192.8\end{array}$

$0.4 \quad 137.9$

$0.8 \quad 139.2$

4.6

3.7

1.4

1.5

1.4

9.3

10.1

9.8

13.9

16.0

5.7

1.2

1.7

2.5

0.0

0.0

0.0

2.5

2.4

5.5

3.5

12.7

12.7

8.5

6.4

13.6

13.8

3.3

5.9
2.3

2.4

1.5

0.7

0.7

0.0

1.4

0.6

1.0

0.9

0.0

0.0

3.6

3.3

1.7

140.1

141.8

326.3

343.6

588.0

585.9

361.1

370.8

307.8

312.4

249.9

249.9

243.1

240.8

179.2

$1.7 \quad 183.3$

$0.9 \quad 152.9$

$0.9 \quad 152.7$

0.8206 .6

$8.1 \quad 204.4$

0.7192 .3

$0.7 \quad 189.6$

$1.8 \quad 360.2$

$1.8 \quad 355.8$

$1.9 \quad 79.6$

$0.6 \quad 92.9$

$0.8 \quad 167.5$

1.1

167.2

20.6

0.1

18.0

18.0

21.8

21.5

16.0

17.0

9.0

8.9

15.3

14.0

12.0

0.0

500.2

143.8

0.0143 .8

$0.8 \quad 264.9$

$1.3 \quad 261.3$

$1.0 \quad 174.8$

0.0186 .0

$1.1 \quad 146.7$

$1.0 \quad 146.5$

$1.5 \quad 198.7$

166.2

150.9

12.0

23.2

22.8

150.0

1.6
0.0

0.0
9.3

6.6

5.3

0.0

0.0

50.3

49.1

12.2

15.3

6.8

6.7

4.9

10.1

27.8

27.0

41.9

47.3

21.4

4.6

7.2

10.6

0.0

0.0

0.0

8.8

17.6

8.8

36.2

35.9

27.5

15.9

372

21.40 .11

3.80 .03

5.40 .04

18.10 .13

18.10 .13

56.50 .17

$\begin{array}{ll}66.5 & 0.19\end{array}$

$\begin{array}{ll}14.8 & 0.03\end{array}$

$\begin{array}{ll}17.7 & 0.03\end{array}$

$\begin{array}{ll}5.8 & 0.02\end{array}$

13.40 .04

$21.7 \quad 0.07$

$14.8 \quad 0.05$

$37.7 \quad 0.25$

13.80 .05 


\begin{tabular}{|c|c|c|c|c|c|c|c|c|c|c|c|}
\hline Well & $\begin{array}{c}\text { Ca } \\
\text { Average } \\
\text { (mg/L) }\end{array}$ & $\begin{array}{c}\mathrm{Ca} \\
\text { Stdev } \\
\text { (mg/L) }\end{array}$ & $\begin{array}{c}\text { Mg } \\
\text { Average } \\
\text { (mgl) }\end{array}$ & $\begin{array}{c}\text { Mg } \\
\text { Stdev } \\
\text { (mg/L) }\end{array}$ & $\begin{array}{l}\text { Hardness } \\
\text { Average } \\
\text { (mg/l) }\end{array}$ & $\begin{array}{c}\text { Hardness } \\
\text { Stdev } \\
\text { (mg/L) }\end{array}$ & CV & $\begin{array}{l}\text { \# of } \\
\text { Values }\end{array}$ & $\begin{array}{l}\text { Flow Thru } \\
\text { time (d) }\end{array}$ & $\begin{array}{l}\mathrm{Q}(\mathrm{m} 3 / \mathrm{s}) \\
\text { Average }\end{array}$ & $\begin{array}{c}Q(\mathrm{~m} 3 / \mathrm{s}) \\
\text { Stdev }\end{array}$ \\
\hline GW-694-WF & 71.0 & 0.0 & 16.0 & 0.0 & 243.1 & 0.0 & & 1 & & 0.7 & 0.0 \\
\hline GW-694-U & 72.0 & 0.0 & 16.0 & 0.0 & 245.6 & 0.0 & & 1 & & 0.7 & 0.0 \\
\hline GW-695-WF & 21.3 & 5.7 & 13.8 & 2.4 & 109.5 & 23.9 & 0.22 & 4 & 2.47 & 11.9 & 4.9 \\
\hline GW-695-U & 29.0 & 3.5 & 14.3 & 4.0 & 131.3 & 22.2 & 0.17 & 3 & 4.01 & 7.6 & 3.1 \\
\hline GW-703-F & 40.0 & 11.9 & 23.8 & 3.9 & 197.4 & 39.2 & 0.20 & 4 & 2.95 & 2.2 & 1.3 \\
\hline GW-703-LU & 31.0 & 2.8 & 22.5 & 3.5 & 169.8 & 7.4 & 0.04 & 2 & 52.93 & 3.3 & 0.5 \\
\hline GW-704-F & 49.3 & 9.8 & 25.3 & 1.0 & 226.7 & 23.7 & 0.10 & 4 & 10.05 & 1.1 & 0.6 \\
\hline GW-704-U & 45.0 & 14.1 & 24.5 & 0.7 & 213.0 & 38.3 & 0.18 & 2 & 3.57 & 1.6 & 1.1 \\
\hline GW-705-mF & 2.4 & 0.6 & 0.7 & 0.1 & 8.7 & 1.6 & 0.19 & 4 & 3.26 & 85.7 & 2.9 \\
\hline GW-705-U & 2.4 & 1.6 & 0.7 & 0.3 & 8.7 & 5.1 & 0.58 & 3 & 0.38 & 85.9 & 8.6 \\
\hline GW-706-F & 36.0 & 0.0 & 19.0 & 0.0 & 167.9 & 0.0 & & 1 & & 3.4 & 0.0 \\
\hline GW-706--U & 36.0 & 0.0 & 19.0 & 0.0 & 167.9 & 0.0 & & 1 & & 3.4 & 0.0 \\
\hline GW-710--F & 580.0 & 0.0 & 210.0 & 0.0 & 2311.0 & 0.0 & & 1 & & 0.0 & 0.0 \\
\hline GW-710--U & 570.0 & 0.0 & 210.0 & 0.0 & 2286.0 & 0.0 & & 1 & & 0.0 & 0.0 \\
\hline GW-711--F & 566.7 & 49.3 & 236.7 & 15.3 & 2387.0 & 182.0 & 0.08 & 3 & 18.32 & 0.0 & 0.0 \\
\hline GW-711--U & 573.3 & 70.2 & 240.0 & 10.0 & 2417.3 & 216.5 & 0.09 & 3 & 13.48 & 0.0 & 0.0 \\
\hline GW-712-F & 115.0 & 7.1 & 48.0 & 0.0 & 484.3 & 17.7 & 0.04 & 2 & 74.75 & 0.0 & 0.0 \\
\hline GW-712-U & 115.0 & 7.1 & 49.5 & 0.7 & 490.5 & 14.8 & 0.03 & 2 & 107.77 & 0.0 & 0.0 \\
\hline$G W-722-10-F$ & 39.0 & 0.0 & 25.0 & 0.0 & 200.0 & 0.0 & & 1 & & 1.7 & 0.0 \\
\hline GW-722-17-F & 47.0 & 0.0 & 30.0 & 0.0 & 240.5 & 0.0 & & 1 & & 0.8 & 0.0 \\
\hline GW-722-20-F & 47.0 & 0.0 & 31.0 & 0.0 & 244.6 & 0.0 & & 1 & & 0.7 & 0.0 \\
\hline GW-722-22-F & 47.0 & 0.0 & 25.0 & 0.0 & 220.0 & 0.0 & & 1 & & 1.2 & 0.0 \\
\hline$G W-722-26-F$ & 43.0 & 0.0 & 20.0 & 0.0 & 189.5 & 0.0 & & 1 & & 2.2 & 0.0 \\
\hline GW-722-30--F & 36.0 & 0.0 & 15.0 & 0.0 & 151.5 & 0.0 & & 1 & & 4.7 & 0.0 \\
\hline GW-722-32--F & 61.0 & 0.0 & 10.0 & 0.0 & 193.5 & 0.0 & & 1 & & 2.0 & 0.0 \\
\hline GW-722-33--F & 62.0 & 0.0 & 10.0 & 0.0 & 196.0 & 0.0 & & 1 & & 1.9 & 0.0 \\
\hline GW-722-6--F & 15.0 & 0.0 & 9.1 & 0.0 & 74.8 & 0.0 & & 1 & & 22.3 & 0.0 \\
\hline GW-723-.F F & 19.0 & 0.0 & 17.0 & 0.0 & 117.2 & 0.0 & & 1 & & 9.4 & 0.0 \\
\hline GW-724--F & 94.0 & 0.0 & 38.0 & 0.0 & 390.8 & 0.0 & & 1 & & 0.0 & 0.0 \\
\hline GW-725--F & 160.0 & 0.0 & 25.0 & 0.0 & 502.5 & 0.0 & & 1 & & 0.0 & 0.0 \\
\hline GW-733--U & 18.0 & 0.0 & 17.0 & 0.0 & 114.7 & 0.0 & 0.02 & 1 & 379.40 & 9.9 & 0.0 \\
\hline GW-733-F & 17.0 & 0.0 & 17.0 & 0.0 & 112.2 & 0.0 & & 1 & & 10.4 & 0.0 \\
\hline GW-734--F & 22.5 & 13.4 & 4.0 & 0.1 & 72.4 & 33.9 & 0.47 & 2 & 0.58 & 26.3 & 16.8 \\
\hline GW-735--U & 110.0 & 0.0 & 8.1 & 0.0 & 308.2 & 0.0 & & 1 & & 0.2 & 0.0 \\
\hline GW-735--F & 110.0 & 0.0 & 8.4 & 0.0 & 309.4 & 0.0 & & 1 & & 0.2 & 0.0 \\
\hline GW-736--U & 170.0 & 0.0 & 20.0 & 0.0 & 507.0 & 0.0 & & 1 & & 0.0 & 0.0 \\
\hline GW-737--U & 180.0 & 0.0 & 24.0 & 0.0 & 548.4 & 0.0 & & 1 & & 0.0 & 0.0 \\
\hline GW-738--U & 110.0 & 0.0 & 24.0 & 0.0 & 373.4 & 0.0 & & 1 & & 0.1 & 0.0 \\
\hline GW-739-.-U & 56.0 & 0.0 & 27.0 & 0.0 & 250.7 & 0.0 & & 1 & & 0.6 & 0.0 \\
\hline GW-739---F & 55.0 & 0.0 & 26.0 & 0.0 & 244.1 & 0.0 & & 1 & & 0.7 & 0.0 \\
\hline GW-740--U & 59.0 & 0.0 & 28.0 & 0.0 & 262.3 & 0.0 & & 1 & & 0.5 & 0.0 \\
\hline GW-740--F & 61.0 & 0.0 & 29.0 & 0.0 & 271.4 & 0.0 & & 1 & & 0.4 & 0.0 \\
\hline
\end{tabular}




\section{DISTRIBUTION}

DEPARTMENT OF ENERGY

G. W. Bodenstein

W. G. McMillan

HEALTH, SAEETY,ENVIRONMENT, AND ACCOUNTABILITY ORGANIZATION

W. K. Jago

S. B. Jones

S. W. Wiley

File-GWPP-RC
ENVIRONMENTAL SCIENCES DIVISION

T. O. Early

R. B. Dreier

D. D. Huff

D. B. Watson

UNIVERSITY OF NEVADA, RENO

L. A. Shevenell (3)

HSW ENVIRONMENTAL CONSULTANTS

J. R. Walker

ENVIRONMENTAL RESTORATION PROGRAM

H. L. King (2)
Y-12 Central Files

A.-K-Lee/DOE-OSTI(2)] 